\title{
Air Quality Trends in Metropolitan Zones in Veracruz, México
}

\author{
Sergio Natan González Rocha',2, Juan Cervantes Pérez³, José M. Baldasano Recio ${ }^{2,4}$ \\ ${ }^{1}$ Facultad Ciencias Químicas, Universidad Veracruzana, Veracruz, Mexico \\ ${ }^{2}$ Earth Sciences Department, Barcelona Supercomputing Center (BSC-CNS), Barcelona, Spain \\ ${ }^{3}$ Centro de Ciencias de la Tierra, Universidad Veracruzana, Veracruz, Mexico \\ ${ }^{4}$ Universitat Politecnica de Catalunya, Barcelona, Spain \\ Email:ngonzalez@uv.mx,jcervantes@uv.mx,jose.baldasano@upc.edu
}

Received 1 April 2016; accepted 14 June 2016; published 17 June 2016

Copyright (C) 2016 by authors and Scientific Research Publishing Inc.

This work is licensed under the Creative Commons Attribution International License (CC BY). http://creativecommons.org/licenses/by/4.0/

(c) () Open Access

\begin{abstract}
Mexico and currently in Veracruz state, there are metropolitan zones (MZ) growing. Therefore, main objective in this paper is to analyze new data and $A Q$ trends during 01.09.2013 to 30.06.2015 of two new AQ monitoring stations installed in Xalapa and Minatitlan MZ in 2013-year. The methodology applied used quality criteria to the datasets, followed by data validation and statistics for further analysis to determine the hourly, weekly and yearly trends of $\mathrm{NO}_{2}, \mathrm{O}_{3}, \mathrm{SO}_{2}, \mathrm{PM}_{10}$ and $\mathbf{P M}_{2.5}$. Indicators were compared with Mexican standards, CAI-LAC report, WHO guidelines, EU and USA standards to evaluate the $A Q$ in both sites. We observed $A Q$ trends from moderate to bad in Xalapa and Minatitlan MZ where the $P M_{10}$ and $\mathrm{PM}_{2.5}$ surpassed the WHO guidelines and Mexican standards. $\mathrm{O}_{3}$ and $\mathrm{SO}_{2}$ in Xalapa presented a quality from good to moderate and in Minatitlan sometimes were from moderate to bad. $\mathrm{NO}_{2}$ did not exceed the value limits of Mexican standards, only Xalapa has exceeded the WHO guidelines. In Minatitlan, the Mexican limits were not exceeded. Concluding, $\mathbf{P M}_{10}$ and $\mathbf{P M}_{2.5}$ concentrations were the main problem. Others pollutants that influenced the $\mathrm{AQ}$ were $\mathrm{O}_{3}, \mathrm{NO}_{2}$ and $\mathrm{SO}_{2}$ in Minatitlan $\mathrm{MZ}$ due probably to meteorology, site conditions, location and oil and petrochemical industries. In Xalapa, $\mathrm{MZ} \mathrm{NO}_{2}$ and $\mathrm{SO}_{2}$ are attributed mainly to road transport.
\end{abstract}

\section{Keywords}

Air Pollution, Air Quality Management, Air Quality Trends, $\mathrm{NO}_{2}, \mathrm{O}_{3}, \mathrm{PM}_{10}, \mathrm{PM}_{2.5}, \mathrm{SO}_{2}$, Veracruz

\section{Introduction}

Air quality in the world is a current concern for both developed and developing countries. The WHO Global

How to cite this paper: González Rocha, S.N., Cervantes Pérez, J. and Baldasano Recio, J.M. (2016) Air Quality Trends in Metropolitan Zones in Veracruz, México. Open Journal of Air Pollution, 5, 64-94.

http://dx.doi.org/10.4236/ojap.2016.52007 
Health Observatory Data Repository [1], reported that 53 per 100,000 capita global deaths were attributable to ambient air pollution, 3,732,500 deaths average. The deaths per 100,000 capita by regions are: Western Pacific 102, European 75, South-East Asia 51, Eastern Mediterranean 42, Africa 20 and the Americas 10. The data observed show the impact on human health from pollutants such as particulate matter $\left(\mathrm{PM}_{10}\right.$ and $\left.\mathrm{PM}_{2.5}\right)$, ozone $\left(\mathrm{O}_{3}\right)$, nitrogen oxides $\left(\mathrm{NO}_{\mathrm{x}}\right)$ and sulphur dioxide $\left(\mathrm{SO}_{2}\right)$. Sources of anthropogenic emissions of industry, power generation, transport, livestock and agricultural are modifying air quality [2]. In the European Union, the appliance of the 2008/50/CE Directive has modified trends in EU countries [3] [4].

Several studies of trends in air pollution and air quality (AQ) have been carried out in different parts of Europe, Asia, the UK and America. Verstreng et al. conducted an analysis over twenty five years in $\mathrm{SO}_{2}$ emissions, going from 1980 to 2004, in which they conclude that European $\mathrm{SO}_{2}$ emissions dropped by 73\%, with a gradual decrease of $55 \mathrm{Tg} \mathrm{SO}$ in 1980 to $15 \mathrm{Tg} \mathrm{SO}_{2}$ in 2004, mainly consisting of anthropogenic emissions from the energy and industrial sectors, these results being due to the framework and targets set in the Gothenburg protocol [5]. Other example is the Mace Head station in Ireland, where trends over a period of 20 years are analyzed in superficial $\mathrm{O}_{3}$ [6]. It was observed in the analysis of hourly $\mathrm{O}_{3}$ measurements that variants existed in annual patterns, which increased and decreased according to events such as biomass burning lights in 1998/1999 and $2002 / 2003$, or patterns of methane in the 2000s. Trends showed higher concentrations of $\mathrm{O}_{3}$ in the spring and lowest in summer periods, producing a significant increase in the amplitude of the seasonal cycle; over the period the annual mean baseline $\mathrm{O}_{3}$ mixing ratios have risen by $0.60 \pm 0.23 \mu \mathrm{g} / \mathrm{m}^{3} \cdot \mathrm{year}^{-1}$.

The trends of nitrogen oxides have also been analyzed in nine European cities between 1999 and 2010. Henshel et al. analyzed the various patterns of NOx from traffic, noting that in the analysis of diurnal, weekly, seasonal and interannual patterns of the nine cities surveyed showed reductions in primary emissions related to traffic after the implementation of the EURO standards [7]. When stratified in periods according the EURO standards, the ratio $\mathrm{NO}_{2} / \mathrm{NOx}$ increased in $7 / 9$ cities, $\mathrm{NO} / \mathrm{NO}_{2}$ ratio decreased in $8 / 9$ cities and a permanent inversion in $\mathrm{NO} / \mathrm{NO}_{2}$ ratio was observed to occur in 2003 in 5/9 cities. Nguyen and Kim analyzed the nitrogen dioxide $\left(\mathrm{NO}_{2}\right)$ in cities and major provinces in Korea from 1998 to 2003, finding that concentrations of this gas reflected changes due to environmental conditions and seasonal patterns, where the highest levels were observed in winter, with decreasing patterns during spring, autumn and summer [8]. These observed levels of $\mathrm{NO}_{2}$ pollution were spatially distributed in greater numbers over highly populated urban areas with peaked values from 38 to 56 $\mu \mathrm{g} / \mathrm{m}^{3}$ (with a single case at $75 \mu \mathrm{g} / \mathrm{m}^{3}$ ) compared with rural areas, which showed values from 38 to $47 \mu \mathrm{g} / \mathrm{m}^{3}$.

In 2011, the Clean Air Institute in Washington carried out the analysis of trends in air quality since 1997. This report was carried out with information from 8 countries and 22 cities, including Mexico, highlighting the air quality prevailing in these cities based on analysis of their standards and existing stations for monitoring pollutants such as $\mathrm{O}_{3}, \mathrm{SO}_{2}, \mathrm{NO}_{2}$ and particulate matter, among others [9]. Baldasano et al. conducted an assessment of the AQ in major cities in developed and developing countries from 1990 to 2000 by comparing the data reported by each agency in these countries with those recommended by the WHO guidelines and EU thresholds [10]; results found that $\mathrm{SO}_{2}$ maintained a downward trend in overall worldwide except for some cities in Central America and Asia. The trend in Mexico City (MC) was downward from 150 to $48 \mu \mathrm{g} / \mathrm{m}^{3} ; \mathrm{NO}_{2}$ showed close to WHO guidelines values, the trend in Mexico City was downward from 90 to $42 \mu \mathrm{g} / \mathrm{m}^{3} ; \mathrm{O}_{3}$ shows on the contrary a tendency to exceed pre-set thresholds: in MC the trend was from 600 to $500 \mu \mathrm{g} / \mathrm{m}^{3} ; \mathrm{PM}_{10}$ as the biggest problem was observed in almost all of Asia, with values that exceeded $300 \mu \mathrm{g} / \mathrm{m}^{3}$. MC maintained a value of 60 $\mu \mathrm{g} / \mathrm{m}^{3}$. In poor and emerging economies, thresholds were observed above the comparison standards.

Lanzafame et al. did a comprehensive study in Catanya (Italy), Sicily's second largest city [11]. In their research, it was found that changes toward diesel as transport fuel affected the concentrations of $\mathrm{NO}_{2}$ and $\mathrm{PM}_{10}$ and corresponded to a decrease in concentrations of $\mathrm{SO}_{2}$ and CO. Titos et al. found in Granada (Spain) and Ljubljana (Slovenia) that application of local regulations on road transport reduced significantly the values in black carbon (BC) and $\mathrm{PM}_{10}$; In Ljubljana, a $72 \%$ reduction from 5.6 to $1.6 \mu \mathrm{g} / \mathrm{m}^{3}$ in local BC; in Granada a 33\% reduction in $\mathrm{PM}_{10}$ and $37 \%$ in $\mathrm{BC}$ were observed as result of closing streets to private traffic, so the renewal and reorganization of the public transport had significantly benefited air quality [12].

Kanabkaew et al. in Nakhon Si Thamarat (Thailand), assessed levels of $\mathrm{PM}_{10}$ and $\mathrm{PM}_{2.5}$ in three main traffic intersections and found that concentration exceeded the average 24-hour guidelines of WHO and the National Air Quality Standard (NAAQ-USA, 2012a) in both pollutants [13]. Prakash et al. used the monthly AQ station data sets of $\mathrm{PM}_{10}$ measured in seven major cities in Korea (1996 to 2010), and found that long-term data concentrations of $\mathrm{PM}_{10}$ had decreased consistently in six of seven cities between 1996 and 2010, reflecting the ef- 
fects of the emissions control. Although the $\mathrm{PM}_{10}$ concentration level from the WHO was exceeded, the annual mean oscillated between $29-77 \mu \mathrm{g} / \mathrm{m}^{3}[14]$.

\section{Air Quality and Health in Mexico}

In the Mexico City, metropolitan area [15] was investigated the chronic health effects associated with high concentrations of pollutants and trends of $\mathrm{O}_{3}$ and particulate matter $\left(\mathrm{PM}_{10}\right.$ and $\left.\mathrm{PM}_{2.5}\right)$ for 20 years. The analysis related to $\mathrm{PM}_{2.5}$ and $\mathrm{PM}_{10}$ was carried out in data periods 1989-2012 and 2004-2012 for $\mathrm{PM}_{10}$ and $\mathrm{PM}_{2.5}$ respectively; trends only considered the arithmetic mean concentration and the 95th percentile of 24-hour concentrations. In selected areas of the industrial "Xalostoc" and "La Merced" sites, the $\mathrm{PM}_{10}$ highest values were obtained which persistently exceeded the Mexican AQ standard, reaching values of $40 \mu \mathrm{g} / \mathrm{m}^{3}$ to $370 \mu \mathrm{g} / \mathrm{m}^{3}$ and 30 $\mu \mathrm{g} / \mathrm{m}^{3}$ to $210 \mu \mathrm{g} / \mathrm{m}^{3}$ respectively. As for $\mathrm{PM}_{10}$, "Xalostoc" was the site with the highest $\mathrm{PM}_{2.5}$ levels and "Pedregal" with the lowest values. As regards $\mathrm{O}_{3}$, trends were reviewed in two representative sites, Tlalnepantla and Pedregal, using the mobile average of 8-h recorded at the monitoring stations. It was observed that in both places the respective 95th percentile had continuously exceeded the WHO guideline between 1989 and 2012. They concluded that exposure to levels above the AQ standards for $\mathrm{PM}_{10}, \mathrm{PM}_{2.5}$ and $\mathrm{O}_{3}$ in air had promoted negative schooling effects, neurodegenerative consequences in the short and likely long term, cortical and subcortical damage linked to antisocial behavior, learning difficulties, promotion of crime or criminal activity impulses along with other effects related to brain damage and pathogenesis for Alzheimer and Parkinson diseases.

Mexico, in common with many countries, is growing and developing in different areas due to different economical activities; according to the National Council of Population (CONAPO, in its Spanish acronym) in 2010, there were 59 metropolitan zones (MZ) with more than 500,000 inhabitants; for example the MZ of Mexico city have around 20 million inhabitants [16] and several problems inherent to a big city; AQ problems are some of them. However, some other MZs deserve attention, as in the case of Veracruz in Mexico, where there are now nine MZs, amounting to $15.3 \%$ of all MZs in the state.

Regarding the aforementioned, the main objective of this paper is to analyze the observed trends in AQ during the period 01.09.2013 to 30.06.2015 in the MZs of Xalapa and Minatitlan in Veracruz state in Mexico, usingair quality validation criteria applied to database observations of monitoring stations located at each site.

\section{Material and Methods}

\subsection{Study Region}

The Veracruz state is a narrow strip of slightly curved land which extends from northeast to southeast on the east coast of Mexico, bordered on the north by the state of Tamaulipas, on the east by the Gulf of Mexico and the state of Tabasco, southeast by the state of Chiapas, south by the state of Oaxaca and west by the states of Puebla, Hidalgo and San Luis Potosi. This analysis was held with data of AQ stations from SEDEMA, situated in the central and southern area of the Veracruz state in the MZs of Xalapa and Minatitlan, their locations shown in Figure 1.

In Veracruz there are 14 power plants from CFE (the Spanish acronym for the Federal Commission of Electricity) and are distributed in the north, center and south of Veracruz; near the MZ are four power plants which generate 579.4 MW [17]. These power plants and oil industries emit pollutants such as $\mathrm{SO}_{\mathrm{x}}, \mathrm{NO}_{\mathrm{x}}, \mathrm{PM}, \mathrm{CO}$, VOCs, $\mathrm{CO}_{2}$ and many compounds related to their industrial process. Veracruz is a state with $745 \mathrm{~km}$ of coastline, with three cabotage ports; one International and two national airports; there are 24,378 km of roads and two railroads, one from Veracruz port and another from Coatzacoalcos port to Mexico City. The state has $1807 \mathrm{~km}$ of railroads. The MZs are distributed along the state and make use of this communication infrastructure [18].

\subsubsection{Xalapa MZ}

The Xalapa MZ consists of seven municipalities in the central area of the state. There are 666,535 inhabitants, distributed over $867 \mathrm{~km}^{2}$. The central municipalities are Xalapa, Banderilla and Tlalnelhuayoca; Xalapa is the capital city of the Veracruz state; it is an urban development and has the second most highly populated MZ in the state which, according [19] has 457,614 inhabitants. Xalapa municipality is located between $19^{\circ} 29^{\prime} \mathrm{N}$ $19^{\circ} 36^{\prime} \mathrm{N}$ and $96^{\circ} 48^{\prime} \mathrm{W}-96^{\circ} 58^{\prime} \mathrm{W}$ [20] [21]. The Xalapa MZ has a national airport located in the Emiliano Zapata municipality. There are $129 \mathrm{~km}$ of roads in the central municipalities and 116,997 vehicles registered in the state 


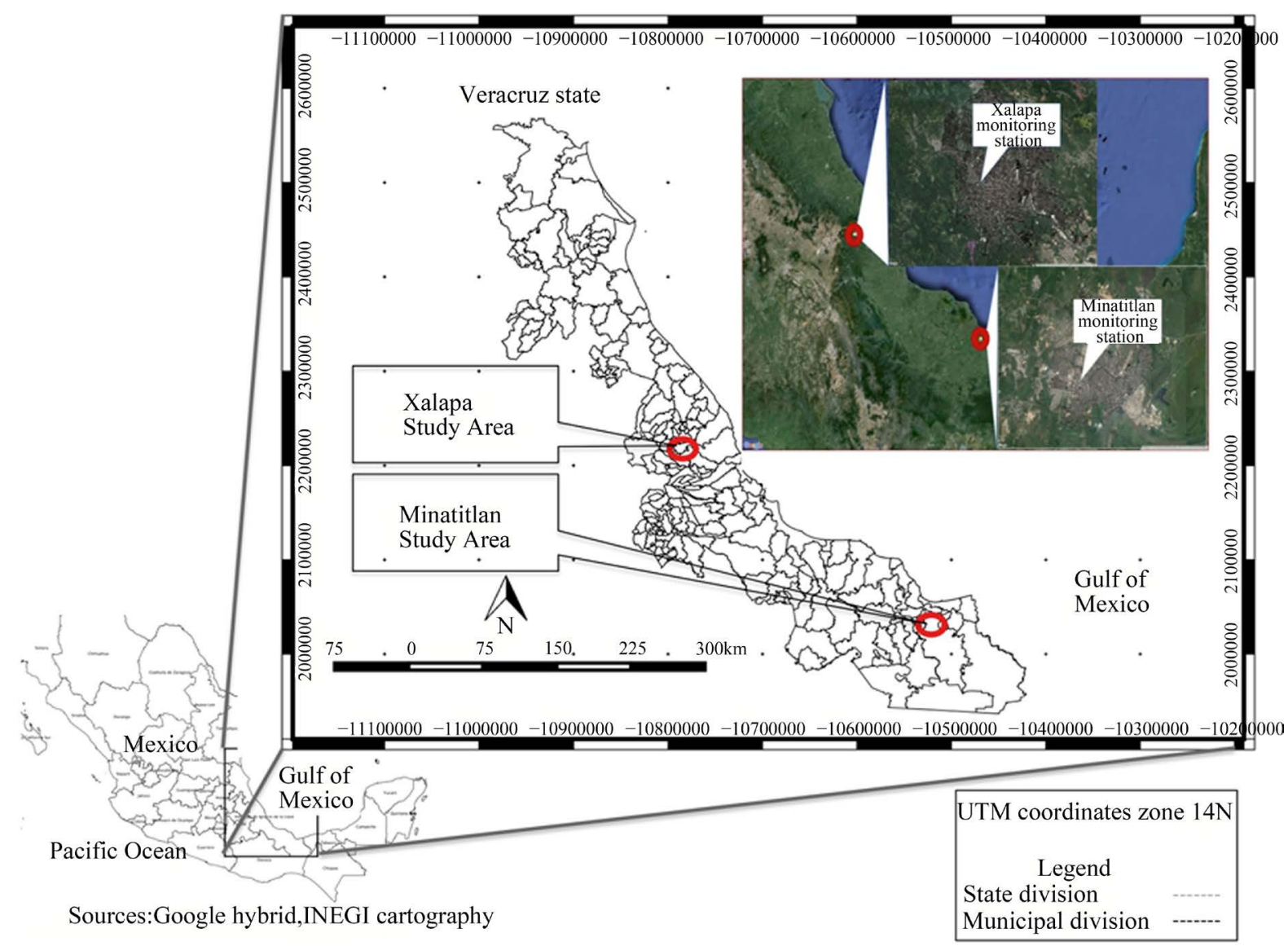

Figure 1. AQ stations, located in central and southern areas of Veracruz state in MZs of Xalapa and Minatitlan.

road transport vehicular reports [18]. The main activities are related to farming, forestry, manufacturing industry, construction, trade and tourism; as a capital city it has several government offices. The climate is humid and varied, with an average maximum temperature of $25^{\circ} \mathrm{C}$ and a minimum from $11.2^{\circ} \mathrm{C}$ to $17.3^{\circ} \mathrm{C}$ in the morning. The altitude ranges are $1250 \mathrm{~m}$ to $1560 \mathrm{~m}$. It has an average annual temperature of $18^{\circ} \mathrm{C}$ and a temperate climate. Its annual average rainfall is $1500.9 \mathrm{~mm}$ (see Table 1) [23].

\subsubsection{Minatitlan MZ}

The Minatitlan MZ consists of six municipalities in the southeast area of the state. It has a population of 356,137 distributed over $2930.3 \mathrm{~km}^{2}$. The central municipalities are Cosoleacaque, Chinameca, Minatitlan and Oteapan, the most populated municipalities being Cosoleacaque with 117,725 and Minatitlan with 157,840 inhabitants [19]. The altitude ranges are $5 \mathrm{~m}$ to $400 \mathrm{~m}$ and the location falls between $17^{\circ} 19^{\prime} \mathrm{N}-18^{\circ} 06^{\prime} \mathrm{N}$ and $94^{\circ} 07^{\prime} \mathrm{W}-$ $94^{\circ} 39^{\prime} \mathrm{W}$ [22]. The Minatitlan MZ has an international airport located in the Cosoleacaque municipality, has 514 $\mathrm{km}$ of roads and there is a railroad from Coatzacoalcos to Mexico City; according reference [18] there are 75,283 vehicles.

The main activities are related to the petroleum refining and petrochemical industries; there are two plants in the city. The secondary activities are agriculture, cattle and livestock, trade, manufacturing industry, construction and tourism. The climate is warm and humid, with an annual average temperature of $25.8^{\circ} \mathrm{C}$; abundant rain in summer and early fall; between May and June the maximum temperatures are $42^{\circ} \mathrm{C}$ to $44^{\circ} \mathrm{C} ; 28^{\circ} \mathrm{C}$ in winter. In January and February lower temperatures tend not to drop below $14^{\circ} \mathrm{C}$ [23] (see Table 2). The region has different climatic subtypes, determined by the mountain variations, producing a rain shadow effect over the western plains. The eastern slopes catch moisture from the Gulf of Mexico, so rainfall there measures between 3000 and $4000 \mathrm{~mm}$ annually. The MZ has an important river basin feeding the "Coatzacoalcos River".

In summary, there are characteristics that differentiate both places. The first of these is the climate: in Xalapa, 
Table 1. Xalapa, average monthly temperature and rainfall.

\begin{tabular}{ccccccccccccccc}
\hline & \multicolumn{1}{c}{ Months } & \multicolumn{1}{c}{ Annual } \\
\cline { 2 - 6 } & Jan & Feb & Mar & Apr & May & Jun & Jul & Ago & Sep & Oct & Nov & Dec \\
\hline Temp. Max., ${ }^{\circ} \mathrm{C}$ & 21.9 & 22.8 & 26.6 & 26.9 & 28.3 & 25.8 & 25.2 & 25.7 & 25.7 & 25.0 & 23.7 & 22.6 & 25.0 \\
Temp. Ave., ${ }^{\circ} \mathrm{C}$ & 16.7 & 17.0 & 20.4 & 21.2 & 22.8 & 20.9 & 20.6 & 21.0 & 21.0 & 20.1 & 18.8 & 17.4 & 19.8 \\
Temp. Min., ${ }^{\circ} \mathrm{C}$ & 11.4 & 11.2 & 14.2 & 15.5 & 17.3 & 16.1 & 15.9 & 16.2 & 16.4 & 15.2 & 14.0 & 12.2 & 14.6 \\
Rainfall, mm & 42 & 38 & 46 & 61 & 121 & 327 & 203 & 171 & 270 & 105 & 66 & 49 & 1500.9 \\
\hline
\end{tabular}

Table 2. Minatitlan, average monthly temperature and rainfall.

\begin{tabular}{|c|c|c|c|c|c|c|c|c|c|c|c|c|c|}
\hline \multirow{2}{*}{ Parameter } & \multicolumn{12}{|c|}{ Months } & \multirow[t]{2}{*}{ Annual } \\
\hline & Jan & Feb & Mar & Apr & May & Jun & Jul & Ago & Sep & Oct & Nov & Dec & \\
\hline Temp. Max., ${ }^{\circ} \mathrm{C}$ & 26.5 & 27.9 & 30.9 & 33.4 & 34.9 & 33.6 & 32.3 & 32.2 & 32.2 & 30.9 & 29.5 & 27.2 & 31.0 \\
\hline Temp. Ave., ${ }^{\circ} \mathrm{C}$ & 22.1 & 23.0 & 25.0 & 27.2 & 28.7 & 28.0 & 27.2 & 27.2 & 27.0 & 26.1 & 24.8 & 22.9 & 25.8 \\
\hline Temp. Min., ${ }^{\circ} \mathrm{C}$ & 17.7 & 18.0 & 19.1 & 20.9 & 22.4 & 22.3 & 22.2 & 22.2 & 21.9 & 21.3 & 20.0 & 18.6 & 20.6 \\
\hline Rainfall, mm & 109 & 53 & 40 & 34 & 114 & 267 & 283.5 & 357 & 467 & 388 & 230 & 146 & 2492.3 \\
\hline
\end{tabular}

the MZ has temperate, cool weather in contrast to the warm-wet weather in the Minatitlan MZ. Rainfall is more intense in the Minatitlan area than in the MZ in Xalapa. In terms of location there is a difference in altitude of $1500 \mathrm{~m}$ between the two areas, because Xalapa is located close to the Neovolcanic belt and the Sierra Madre Oriental, in contrast to Minatitlan MZ, which is located on the coastal plain of the Gulf of Mexico. Considering its industrial profile, Xalapa hosts more urban and commercial activity than Minatitlan, but in the MZ of Minatitlan there are oil refining, petrochemical and agrochemical companies. Finally, the population density is much higher in the MZs of Xalapa than in Minatitlan's MZ. A similarity is that both places are nodes of main roads in the state.

\subsubsection{Meteorological Influences}

The climate in the state of Veracruz varies from warm sub-humid in coastal areas, through temperate, dry, semi-dry and cold found in the mountains, called "Pico de Orizaba" and "Cofre de Perote". According to the Köeppen classification there are climates A (Warm), B (Arid), C (Temperate) and E (Cold) [24]. The mean annual temperature is $23^{\circ} \mathrm{C}$ from April to May, mean maximum temperature is $32^{\circ} \mathrm{C}$; the mean minimum temperature is $13^{\circ} \mathrm{C}$ and usually comes in January. Annual average rainfall in the state is $1500 \mathrm{~mm}$. The rainy season starts in summer from June until October; in Tabasco state border it can rain throughout the year [25]. In August and July temperature increases and rain lessens, an effect called "Canícula" [26]; this change increases the ambient temperature between $30^{\circ} \mathrm{C}$ to $45^{\circ} \mathrm{C}$ or more in coastal areas, and generally throughout the state. The Gulf of Mexico has great influence on wind patterns. The winds have intense variability, primarily under the influence of the hurricane season between May and November, and cold fronts between September and May. The winds outside of these seasons are weak. Cold fronts, usually called "Norths", are intense winds from the northwest USA, arriving from the fall. The long-term monthly mean wind direction in the northern Gulf is mainly westward, with a small southward component [27]. In the analyzed period between 2013 to 2014, observations were made by the Mexican Navy (SEMAR in its Spanish acronym) and National Weather Service of a total of 12 hurricanes, a tropical depression and three tropical storm incidents mainly in the states of Baja California, Tamaulipas, Oaxaca, Chiapas, Guerrero, Veracruz, Tabasco and Campeche [28]-[30].

Regarding the incidence of direct solar radiation, according reference [31] between 1998-2002 sunlight range was from 3.0 to $6.0 \mathrm{kWh} / \mathrm{m}^{2} /$ day; in north regions the values were from 3.5 to $4.0 \mathrm{kWh} / \mathrm{m}^{2} /$ day, in the central region from 3.5 to $6.0 \mathrm{kWh} / \mathrm{m}^{2} /$ day and in the south of the state from 3.0 to $4.5 \mathrm{kWh} / \mathrm{m}^{2} /$ day. Figure 2 and Figure 3 show the correlation between temperature and solar radiation from both stations. 


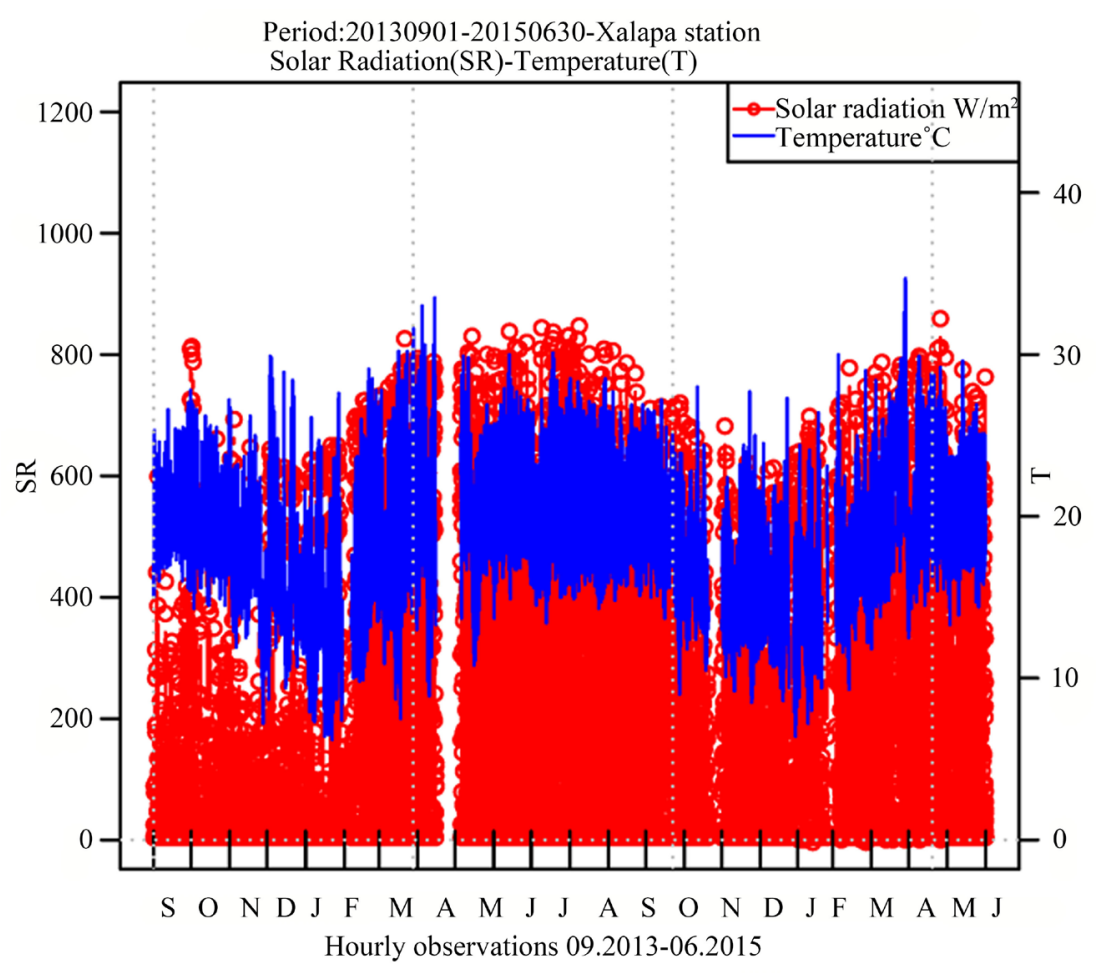

Figure 2. Xalapa station: temperature (T) and solar radiation (SR) Hourly observations from 2013-2015, in the figure its observed the correlation between T and SR, and the seasonal pattern in the period analyzed.

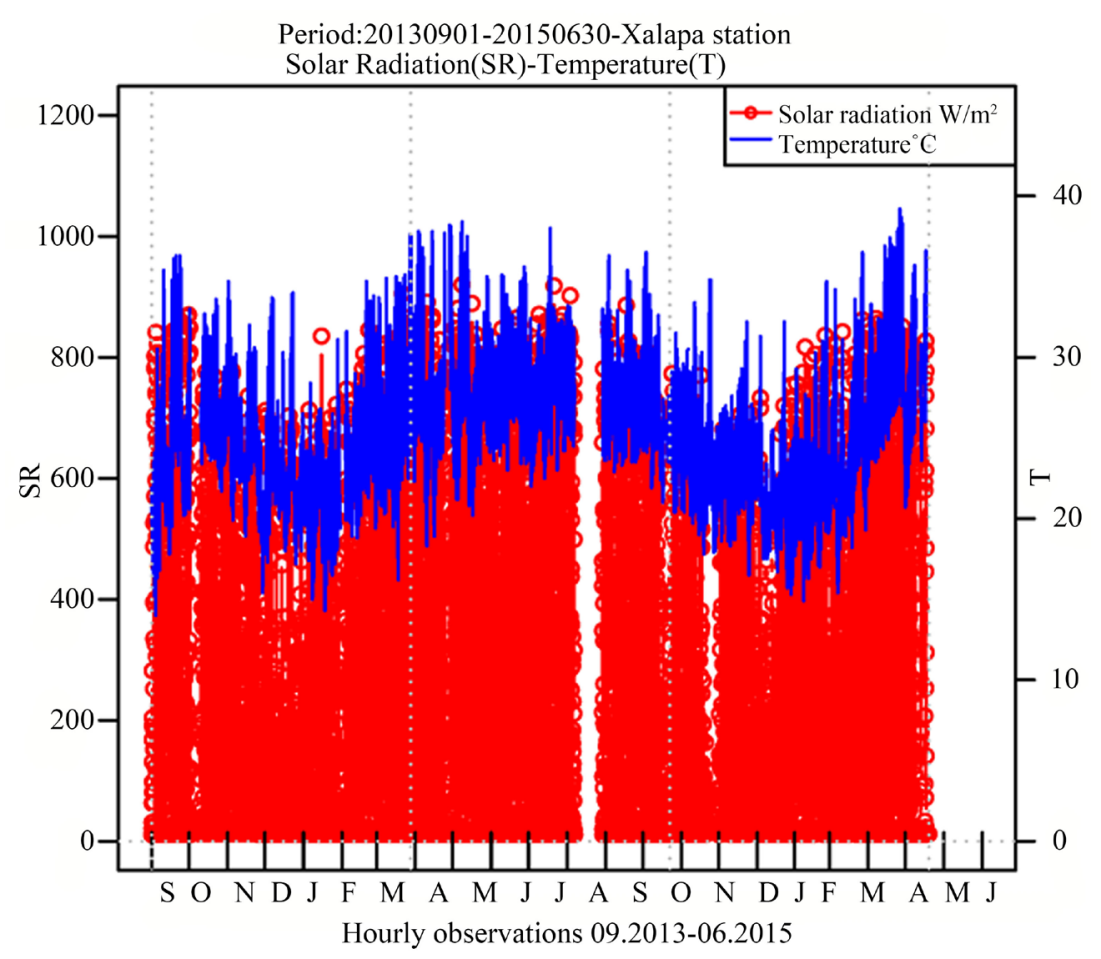

Figure 3. Minatitlan station: temperature (T) and solar radiation (SR) Hourly observations from 2013-2015, in the figure its observed the correlation between T and SR, and the seasonal pattern in the period analyzed. 


\subsection{Air Quality Monitoring Stations Description}

The AQ in the state has been a concern to the general public, academics, researchers, PEMEX, CFE and government in the state of Veracruz; since 2000 there have been various attempts to determine the AQ in cities as Orizaba, Poza Rica, Xalapa, Veracruz city and Coatzacoalcos by SEDEMA, PEMEX and the Universidad Veracruzana (UV); SEDEMA in Veracruz started a program to improve the AQ in the state in February 2013, and two monitoring stations were installed in Xalapa and Minatitlan cities to determine the AQ.

The information of this network is providing AQ data for their analysis and for the decision-making stakeholders in the state [32].

These AQ monitoring stations are shelters that collect data of $\mathrm{O}_{3}, \mathrm{NO}, \mathrm{NO}_{2}, \mathrm{NOx}, \mathrm{SO}_{2}, \mathrm{CO}, \mathrm{PM}_{10}, \mathrm{PM}_{2.5}$ and meteorological variables such as wind direction (WD), wind speed (WS), temperature (TMP), relative humidity $(\mathrm{RH})$, barometric pressure (BP), rainfall (R) and solar radiation (SR). The shelter dimensions are $2.4 \times 2.4 \times 2.4$ $\mathrm{m}$, the air intake has a removable vertical glass manifold sampler of $0.0254 \mathrm{~m}$ diameter, with sampling ports, thermal isolation, protection against rain and dust, Teflon pipes of $0.00635 \mathrm{~m}$ gauge and $0.0031 \mathrm{~m} \mathrm{ID}$ for the gas analyzers. It has two mounting racks to counter vibration and an external staircase. The meteorological tower is telescopic and retractile, $10 \mathrm{~m}$ high and featuring one unit of air conditioning; the shelter power is regulated and has power failure backup from an uninterruptible power supply (UPS). The PM air intake is $0.0254 \mathrm{~m}$ in diameter for the removable sampling tube in the automatic PM analyser.

\subsubsection{AQ Monitoring Stations Location and Area Description}

The AQ monitoring station in Xalapa city is located in a government office at $19^{\circ} 32^{\prime} 11.74 " \mathrm{~N}$ and $96^{\circ} 55^{\prime} 52.29^{\prime \prime} \mathrm{W}$ at 1430 m.a.s.l. (metres above sea level), address Ave. Manuel Avila Camacho, 195, Colonia Ferrer Guardia. This location is central downtown; highest buildings in the area are 4 to 12 meters and the location is next to local streets and one collector road with a hilly topography.

The AQ monitoring station in Minatitlan city is located in a higher education centre, the Technological Institute of Minatitlan, at $18^{\circ} 0^{\prime} 25.86 " \mathrm{~N}$ and $94^{\circ} 33^{\prime} 26.76^{\prime \prime} \mathrm{W}$ at 22 m.a.s.l. (metres above sea level), address Ave. Instituto Tecnologico, Colonia Buena Vista Norte. This is an urban location, and the avenue is considered a main road. $3.4 \mathrm{~km}$ northwest there is an oil refining plant and at $500 \mathrm{~m}$ northeast there is one petrochemical plant, both belong PEMEX. The highest buildings in the area are 4 to $8 \mathrm{~m}$. In general the region is considered a coastal area, with hills 50 m.a.s.l. (see Figure 4).

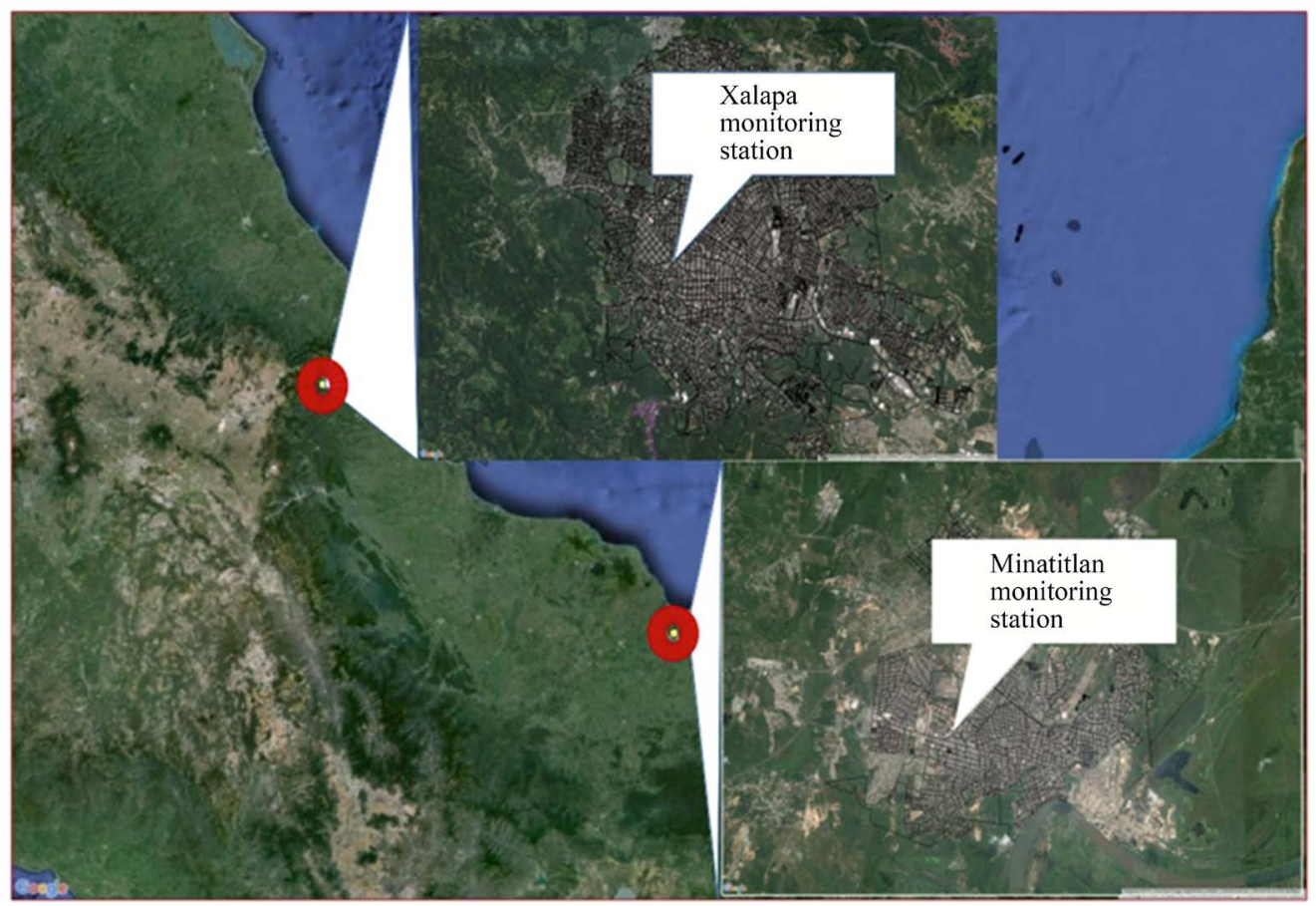

Figure 4. Monitoringstations location in Xalapa and Minatitlan cities in Veracruz, Mexico. 


\subsubsection{Analysis Methods}

Ozone $\left(\mathrm{O}_{3}\right)$ : The method used by the analyzer TELEDYNE T400 is UV photometry to determine the concentration values of ambient $\mathrm{O}_{3}$ monitors, the equipment has a range from 0 to 100 parts per billion (ppb) or 0 to 10 parts per million (ppm). This method has been widely used for almost 20 years in preference to the chemiluminescense (CL) reference method [33].

Nitrogen oxides ( $\mathrm{NO}, \mathrm{NO}_{2}$ and $\mathrm{NO}_{\mathrm{x}}$ ): The $\mathrm{NO}, \mathrm{NO}_{2}$ and $\mathrm{NO}_{\mathrm{x}} \mathrm{CL}$ analyzers are used in the current EPA standards methods. The gas phase CL is defined as the production of visible or infrared radiation produced by the reaction of two gaseous species to form an excited species product that decays to its ground state by the photo emissive act [33]. The method used in the analyzer TELEDYNE T200 is based on the rapid CL reaction of nitric oxide (NO) with excess ozone $\left(\mathrm{O}_{3}\right)$. This reaction takes place in a light-free chamber. A portion of $\mathrm{NO}_{2}$ is produced and subsequently decays to the ground level state, emitting light in a broad frequency band with a peak at about $1200 \mathrm{~nm}$. The intensity of light emitted is linearly proportional to the NO concentration and is measured by a photomultiplier tube. In this manner, the NO is determined directly in a sample stream as described previously.

Atmospheric $\mathrm{NO}_{2}$ is measured in a stream indirectly after conversion to nitric oxide, and its concentration is calculated by the subtraction from the measured total oxides of nitrogen. The detection and determination of total nitrogen oxides is the sum of $\mathrm{NO}+\mathrm{NO}$ from $\mathrm{NO}_{2}$ described above.

Sulphur dioxide $\left(\mathrm{SO}_{2}\right)$ : The $\mathrm{SO}_{2}$ is measured in the TELEDYNE T100 equipment by UV fluorescence spectrophotometry, which measures the "fluorescence" of light emitted by certain molecules such as $\mathrm{SO}_{2}$ when excited by a radiation source of appropriate energy or wavelength. The loss of energy in transition causes the fluorescence or secondary light of lower energy, and consequently longer wavelength emission than the primary light. The ultraviolet (between $190-230 \mathrm{~nm}$ ) and lower visible wavelengths are more useful as a source of excitation; the decay radiation is passed through a bandwidth filter and into a photomultiplier tube (PMT) that converts the signal into a voltage that can be directly measured [33] [34].

Carbon Monoxide (CO): The TELEDYNE T300 measures low ranges of CO by comparing infrared (IR) energy absorbed by a sample to that absorbed by a reference gas according to the Beer-Lambert law. Using a gas filter correlation wheel, a high energy IR light source is alternately passed through a CO-filled chamber and a chamber with no CO present. The light path then travels through the sample cell, which has a folded path of 14 meters. The energy loss through the sample cell is compared with the span reference signal provided by the filter wheel to produce a signal proportional to concentration, with little effect from interfering gases within the sample [33].

$P M_{10}$ and $P M_{2.5}$ : Met One BAM analyzers are used for measuring $\mathrm{PM}_{10}$ and $\mathrm{PM}_{2.5}$ through beta attenuation measurement (BAM), this method is used in continuous PM measuring and was adapted 40 years ago for use in ambient particle monitoring [35]. The equipment uses particulate dynamic motion, where the biggest size particles are retained in a system and do not reach the filter. The PM is introduced by an air pump system in the BAM, and is deposited on a glass filter tape. Measurements are usually taken from one to 24 hours or until filter saturation is reached. After that, low-level beta radiation is passed through the filtering tape and the particles deposited on the tape. The intensity of the radiation is reduced according the layer of PM on the filter tape, which is sensed by an ionization chamber that transmits a voltage signal proportional to the real mass measurement. The concentration is calculated according the difference in the temporal increase in the particle mass on the glass filter tape [36] [37].

\subsection{Air Quality Data Analysis}

The data obtained from air monitoring equipment are important for the quality of the resulting analysis and the AQ indicators calculated (AQI) [38]. The data organization and validation process are important at this stage for the AQI in Mexico and the analysis of trends related to the Urban Air Pollution (UAP) in the MZs in the Veracruz state. This process can be realized manually, automatically or semi automatically. The data organization and scrubbing was carried out using a semi automatic process and the flags system related with incidents occurring in the measurement process (see Table 3). Power failures, automatic calibration, zero test and span were identified in the operation and system binnacles. In the process the original flags were respected, the raw data were not erased and the data validation and conversion were carried out in new columns [38].

The validation process was necessary to set maximum and minimum values, maximum differences and 
constant values. The minimum values in $\mu \mathrm{g} / \mathrm{m}^{3}$ were one for $\mathrm{O}_{3}, \mathrm{NO}_{2}, \mathrm{SO}_{2}, \mathrm{PM}_{10}$ and $\mathrm{PM}_{2.5}$; the maximum values in $\mu \mathrm{g} / \mathrm{m}^{3}$ were 250 for $\mathrm{O}_{3}, 300$ for $\mathrm{NO}_{2}, 600$ for $\mathrm{SO}_{2}, \mathrm{PM}_{10}$ and $\mathrm{PM}_{2.5}$, used in Kalman filter (KF) [39].

The absolute maximum differences between two consecutive values in $\mu \mathrm{g} / \mathrm{m}^{3}$ were 150 for $\mathrm{O}_{3}, 150$ for $\mathrm{NO}_{2}$, 200 for $\mathrm{SO}_{2}, 120$ for $\mathrm{PM}_{10}$ and 80 for $\mathrm{PM}_{2.5}$. Regarding failures in the measuring equipment, constant values, when observed, were considered suspicious, and the minimum limit applied was $10 \mu \mathrm{g} / \mathrm{m}^{3}$ in the pollutants reviewed. A data set was eventually obtained which was validated for analysis and to calculate the AQ indicators.

AQ indicators procedure: Hourly average (HA), 8-hour average (8HA) and Daily average (DA).

Once data were validated, descriptive statistical tools were used as indicators: the observations number, average, median, mode, percentiles, range, variance, standard deviation, variation coefficients, interquartile range and correlation; with the purpose of identify patterns and trends; daily, monthly and annual graphics were made to represent observations of the monitoring stations in Xalapa and Minatitlan in Veracruz. The HA or hourly concentration is the mean value of minute concentrations or between some time lapses in the hour analysed. This average is calculated over the time period before the hour computed. The 8HA is calculated using the HA concentrations between the reference hour and the seven hours previously registered.

The AQ indicator ascribed to the pollutant is calculated from HA or 8HA and represents the daily maximum (DM), daily average (DA) or 24-hour sampling (24H). The $\mathrm{DM}\left(\mathrm{O}_{3}, \mathrm{NO}_{2}\right.$ and $\left.\mathrm{CO}\right)$ value is the highest concentration of $24 \mathrm{H}$ or $8 \mathrm{HA}$ registered on the reference day, the $\mathrm{DA}\left(\mathrm{PM}_{10}, \mathrm{PM}_{2.5}\right.$ and $\left.\mathrm{SO}_{2}\right)$ is the $24 \mathrm{H}$ averages values registered on the day, the $24 \mathrm{H}\left(\mathrm{PM}_{10}, \mathrm{PM}_{2.5}\right.$ and PST) is the data observation obtained from discontinuous sampling, usually every six days. For the quality assurance of observations a minimum quantity of observations is necessary; compliance of data for every pollutant (see Table 4). Once the HA, 8-HA, DA, DM, and 24H data have been obtained, the next step was to calculate the indicators used in AQ for health impact, behavior or time. According to international and Mexican regulations (see Table 5), the report of indicators is recommended be

Table 3. Flags used in data cleaning process.

\begin{tabular}{cc}
\hline Flag & Data meaning \\
VA & Valid \\
C & Invalidate by calibration \\
IR & Invalidate for operation Range, including max and min limits fixed \\
VZ & Valid equated to zero or limit of detection \\
ND & Not available \\
IF & Invalid for Equipment Failure \\
M & Maintenance perturbation \\
P & Out of service \\
DS & Suspicious data \\
\hline
\end{tabular}

Table 4. Monitoring type, temporality and parameters used in monitoring stations.

\begin{tabular}{|c|c|c|c|}
\hline Sampling type & Data type & Completion requirement of data & Parameters \\
\hline \multirow{5}{*}{ Automatic } & Hourly data & $\begin{array}{l}\text { Must have at least } 75 \% \text { of minute records } \\
\text { (45 minutes or more) }\end{array}$ & $\begin{array}{c}\mathrm{PM}_{10}, \mathrm{PM}_{2.5}, \mathrm{O}_{3}, \mathrm{CO}, \mathrm{SO}_{2}, \mathrm{NO}, \mathrm{NO}_{\mathrm{x}} \text {, } \\
\mathrm{NO}_{2}, \mathrm{TMP}, \mathrm{HR}, \mathrm{WS} \text { and WD }\end{array}$ \\
\hline & 8-hour average & $\begin{array}{l}\text { Must have at least } 75 \% \text { or more of hourly } \\
\text { records ( } 6 \text { - } 8 \text { hours data) }\end{array}$ & $\mathrm{O}_{3}$ and $\mathrm{CO}$ \\
\hline & Daily Maximum & $\begin{array}{l}\text { For hourly data must have at least } 75 \% \text { or } \\
\text { more hourly data (18 hour or more) }\end{array}$ & $\begin{array}{c}\mathrm{O}_{3}, \mathrm{CO}, \mathrm{NO}, \mathrm{NO}_{\mathrm{x}}, \mathrm{NO}_{2}, \mathrm{TMP}, \mathrm{HR} \\
\text { and WS }\end{array}$ \\
\hline & Daily Maximum & $\begin{array}{l}\text { For } 8 \text {-hour average data must have at } \\
\text { least } 75 \% \text { or more records ( } 18 \text { hours or more) }\end{array}$ & $\mathrm{O}_{3}$ and $\mathrm{CO}$ \\
\hline & Daily average & $\begin{array}{l}\text { Must have at least } 75 \% \text { or more hourly } \\
\text { records ( } 18 \text { hours or more) }\end{array}$ & $\mathrm{PM}_{10}, \mathrm{PM}_{2.5}, \mathrm{SO}_{2}, \mathrm{TMP}, \mathrm{HR}$ and WS \\
\hline Manual & 24-hour sampling & $\begin{array}{l}\text { Is valid for a sampling time between } \\
23 \text { - } 25 \text { hours (NOM-035-ECOL-1993) }\end{array}$ & PST, $\mathrm{PM}_{10}, \mathrm{PM}_{2.5}$, and $\mathrm{Pb}$ \\
\hline
\end{tabular}


Table 5. AQ Health impact, patterns and trend indicators.

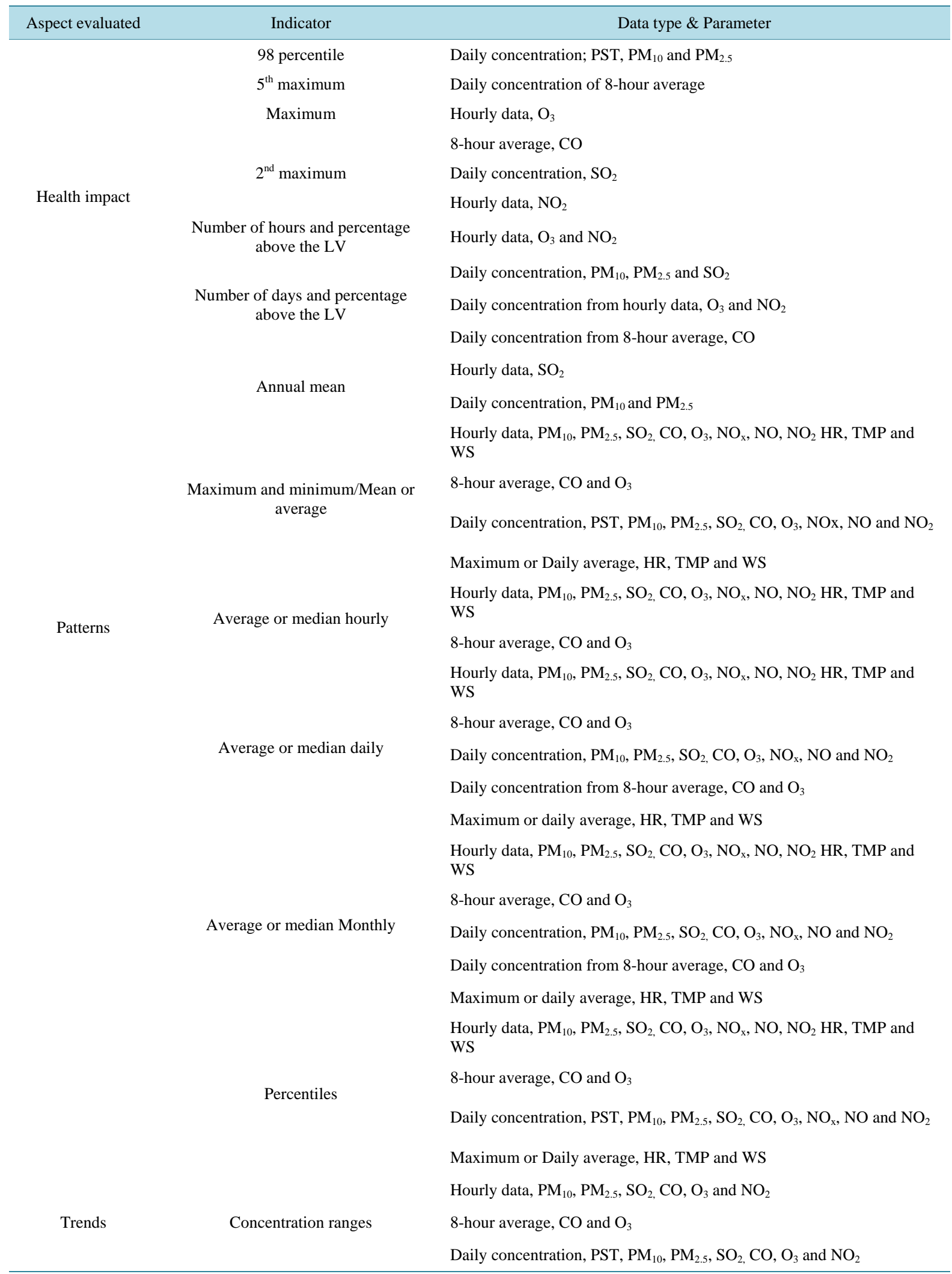

Adapted from INECC-Manual 5. 
done by the monitoring station [38] [40]. Hourly data were analysed using the openair package [41] [42] and in $\mathrm{R}$ statistical software environment [43].

\subsection{Air Quality Standards and Monitoring Stations Classification}

AQ regulations in the USA, EU, Asia, Latin America and many other countries are made for the compliance of WHO guidelines related to AQ and Health. These values are the commitment of many countries to improve their AQ and decrease the damage on nature, morbidity and mortality rates attributed to air pollution worldwide [1] [44]. In this work we compared and analyzed the air quality guidelines of WHO [45], the CE Directive 2008/ 50/CE [44], the NAAQ-USA [46] and the Mexican regulations (termed NOMs) (see Table 6).

Since 1987 in Mexico, the General Law of ecological equilibrium and environmental protection [47] has defined the rules for control and prevention of atmospheric pollution (Spanish acronym: RPCCA) and the emissions and pollutants transference record (Spanish acronym: RETC).

For legal issues, the SEMARNAT is the federal agency that has the responsibility for the establishment of standards at the federal administrative level. These standards are called Official Mexican Standards (Spanish acronym: NOMs); Mexican air quality standards (AQS) will be explained in later paragraphs. In some states in Mexico there are environmental agencies called SEDEMA which use federal and state laws and regulations, and when necessary NOMs are used; The Mexican standards used in this paper were the NOM-020-SSA1-2014, NOM-022-SSA1-2010, NOM-023-SSA1-1993, NOM-025-SSA1-2014 and NOM-156-SEMARNAT-2012 [48].

The monitoring stations can be classified according EPA criteria [49] as Traffic Stations (TS), Area Stations (AS) or Urban Stations (US), Rural Stations (RS), also called Background Stations, Biogenic Stations (BS) and Fixed Stations (FS). According to this, the classification of the stations in the Veracruz state is hence in Xalapa

Table 6. Comparative between AQ world standards.

\begin{tabular}{|c|c|c|c|c|}
\hline Pollutant & {$[1]$} & {$[2]$} & [3] & {$[4]$} \\
\hline $\mathrm{PM}_{2.5}$ & $\begin{array}{c}10 \mu \mathrm{g} / \mathrm{m}^{3} \text {, annual } \\
\text { average } \\
25 \mu \mathrm{g} / \mathrm{m}^{3}, 24 \\
\text { hour average }\end{array}$ & $25 \mu \mathrm{g} / \mathrm{m}^{3}$, annual average & $\begin{array}{c}45 \mu \mathrm{g} / \mathrm{m}^{3} 24 \text { hour average, } \\
12 \mu \mathrm{g} / \mathrm{m}^{3} \text {, annual average }\end{array}$ & $\begin{array}{c}\text { Daily average, } 35 \mu \mathrm{g} / \mathrm{m}^{3}, 98 \\
\text { percentile, } 3 \text { years over average } \\
12 \mu \mathrm{g} / \mathrm{m}^{3} \text { hour average, } 3 \\
\text { years over average }\end{array}$ \\
\hline $\mathrm{PM}_{10}$ & $\begin{array}{c}20 \mu \mathrm{g} / \mathrm{m}^{3} \text {, annual } \\
\text { average } \\
50 \mu \mathrm{g} / \mathrm{m}^{3}, 24 \\
\text { hour average }\end{array}$ & $\begin{array}{c}40 \mu \mathrm{g} / \mathrm{m}^{3} \text {, annual average } \\
50 \mu \mathrm{g} / \mathrm{m}^{3} \text { not to be exceeded } \\
\text { more than } 35 \text { times at a civil } \\
\text { year, } 24 \text { hours average }\end{array}$ & $\begin{array}{c}24 \text { hour limit value: } 75 \mu \mathrm{g} / \mathrm{m}^{3} \text {, } \\
24 \text { hours average, and } \\
\text { Annual limit: } 40 \mu \mathrm{g} / \mathrm{m}^{3} \text {, annual } \\
\text { average }\end{array}$ & $\begin{array}{l}150 \mu \mathrm{g} / \mathrm{m}^{3} \\
\text { Not to be exceeded once a year, } \\
\text { average more than } 3 \text { years }\end{array}$ \\
\hline Ozone $\left(\mathrm{O}_{3}\right)$ & $\begin{array}{c}100 \mu \mathrm{g} / \mathrm{m}^{3}, 8 \\
\text { hours average }\end{array}$ & $\begin{array}{c}180 \mu \mathrm{g} / \mathrm{m}^{3} \text {, hourly average } \\
120 \mu \mathrm{g} / \mathrm{m}^{3} \text { Daily } \\
\text { maximum from 8-hour } \\
\text { average in a civil year }\end{array}$ & $\begin{array}{l}0.095 \mathrm{ppm} \text { or } 186.2 \mu \mathrm{g} / \mathrm{m}^{3} \\
\text { hourly average. } \\
\text { 8-hour average }\left(\mathrm{O}_{3}\right), \text { must be } \\
\text { less than } 0.070 \mathrm{ppm} \text { or } 137.2 \\
\mu \mathrm{g} / \mathrm{m}^{3} \text {, maximum once in one } \\
\text { civil year. }\end{array}$ & $\begin{array}{l}0.075 \mathrm{ppm}, 147 \mu \mathrm{g} / \mathrm{m}^{3} \\
\text { 8-hour average }\end{array}$ \\
\hline $\begin{array}{l}\text { Nitrogen } \\
\text { Dioxide } \\
\left(\mathrm{NO}_{2}\right)\end{array}$ & $\begin{array}{c}40 \mu \mathrm{g} / \mathrm{m}^{3} \text {, annual } \\
\text { average } \\
200 \mu \mathrm{g} / \mathrm{m}^{3}, \\
\text { hourly average }\end{array}$ & $\begin{array}{c}200 \mu \mathrm{g} / \mathrm{m}^{3} \text { Not to be } \\
\text { exceeded more than } \\
18 \text { times in a civil year, } \\
\text { hourly average } \\
40 \mu \mathrm{g} / \mathrm{m}^{3} \text {, annual average }\end{array}$ & $\begin{array}{l}0.21 \mathrm{ppm} \text { equal to } 395 \mu \mathrm{g} / \mathrm{m}^{3} \text {, } \\
\text { one hour once a year }\end{array}$ & $\begin{array}{c}\text { Hourly average, } 191.3 \mu \mathrm{g} / \mathrm{m}^{3}, 98 \\
\text { percentile daily hourly average } \\
\text { concentrations in more } \\
\text { than } 3 \text { years. } \\
101.4 \mu \mathrm{g} / \mathrm{m}^{3} \text {, annual average }\end{array}$ \\
\hline $\begin{array}{l}\text { Sulphur } \\
\text { Dioxide } \\
\left(\mathrm{SO}_{2}\right)\end{array}$ & $\begin{array}{c}20 \mu \mathrm{g} / \mathrm{m}^{3}, 24 \\
\text { hour average } \\
500 \mu \mathrm{g} / \mathrm{m}^{3}, 10 \\
\text { minutes average }\end{array}$ & $\begin{array}{l}350 \mu \mathrm{g} / \mathrm{m}^{3} \text {, Not to be } \\
\text { exceeded more than } 24 \\
\text { times in a civil year, } \\
\text { hourly average. } \\
125 \mu \mathrm{g} / \mathrm{m}^{3} \text { Not to be } \\
\text { exceeded more than } 18 \\
\text { times in a civil } \\
\text { year, daily average }\end{array}$ & $\begin{array}{c}288 \mu \mathrm{g} / \mathrm{m}^{3} \text { or } 0.110 \mathrm{ppm} 24 \\
\text { hours average, once a year. } \\
66 \mu \mathrm{g} / \mathrm{m}^{3} \text { or } 0.025 \mathrm{ppm} \\
\text { annual average. } \\
524 \mu \mathrm{g} / \mathrm{m}^{3}, 8 \text { hours average, } \\
\text { not to be exceeded } \\
\text { twice a year }\end{array}$ & $\begin{array}{c}199.7 \mu \mathrm{g} / \mathrm{m}^{3} 99 \text { percentile, } \\
\text { hourly daily concentration, } 3 \\
\text { years over average }\end{array}$ \\
\hline
\end{tabular}

[1] WHO Guidelines 2005, [2] EU Directive 2008/50/CE, [3] Mexican Regulations (NOM’s) and [4] NAAQS-USA 2011. 
city US-TS and in Minatitlan city US-FS-TS.

\section{Results and Discussion}

The measurement of pollutants analyzed represent the information from the Xalapa and Minatitlan stations and describe the observations of $\mathrm{NO}_{2}, \mathrm{O}_{3}, \mathrm{SO}_{2}, \mathrm{PM}_{10}$ and $\mathrm{PM}_{2.5}$ over the period from 01.09.2013 to 30.06.2015: four months of 2013, the full year of 2014 and six months of 2015; validated data during periods of analysis for Xalapa station account for $74 \%$ and Minatitlan station $73 \%$ of 16,032 hourly observations.

Figures 5-7 shows the patterns of the monitoring station in Xalapa, and Figures 8-10 observations of the Minatitlan monitoring station. From the perspective of analysis concerning the annual limit values, and although the series available do not meet the minimum number of observations, we proceeded to compile the respective time averages. This is why in some of the series at annual periods it is observed that these limit values have been exceeded.

\subsection{Xalapa Air Quality Station}

Figure 5(a) presents the observations of the urban traffic station with mean values $\mathrm{NO}_{2}$ concentration of 30, 22 and $15 \mu \mathrm{g} / \mathrm{m}^{3}$, and a standard deviation of 19,15 and $9 \mu \mathrm{g} / \mathrm{m}^{3}$ in the respective periods. Table 7 summarizes the statistical values of $\mathrm{NO}_{2}$. In $\mathrm{HA}$ values we observed that almost all the values ranged from 1 to $85 \mu \mathrm{g} / \mathrm{m}^{3}$, but in the months 12.2013 and 01.2014 maximum values reached $198 \mu \mathrm{g} / \mathrm{m}^{3}$. The hourly pattern of $\mathrm{NO}_{2}$ in Figure 6 and Figure 7 show that from 06:00 and 10:00 and from 17:00 to 20:00 maximum values were reached; analyzing the weekly pattern, Monday began an increasing trend in $\mathrm{NO}_{2}$ concentrations, peaking on Tuesdays and Thursdays, and decreasing at the weekend. In the monthly analysis, we observed the maximum occurring in the months of January, June, August, October and November; record low values occurred in the months of February and April.

Comparing the hourly observations with international and Mexican standard, Figure 5(a) shows that the HLV of Mexico of $395 \mu \mathrm{g} / \mathrm{m}^{3}$ and the value of $200 \mu \mathrm{g} / \mathrm{m}^{3}$ in the EU were not exceeded during the period. Considering the average annual values, and analyzing 2014, under Mexican law NOM NOM-023-SSA1-1993 [50], the ALV of $40 \mu \mathrm{g} / \mathrm{m}^{3}$ from the WHO was exceeded as shown in Figure 5(a). The 2013 and 2015 observations show the same trend over the ALV from the WHO. These values could have been magnified by meteorological factors such as unusual temperatures and solar radiation values recorded in December 2013 and January 2014 as shown in Figure 2, and some by emission sources in the area related to traffic and the dynamics of the city. The $\mathrm{O}_{3}$ in Figure 5(b) shows the HA and 8HA values; Table 7 shows statistics where it is observed that the values of HA concentrations are 37,43 and $51 \mu \mathrm{g} / \mathrm{m}^{3}$ with standard deviations of 24,27 and $31 \mu \mathrm{g} / \mathrm{m}^{3}$ in the periods analyzed. The maximum value was $169 \mu \mathrm{g} / \mathrm{m}^{3}$, reached in 2014. The minimum values were 1,7 and $8 \mu \mathrm{g} / \mathrm{m}^{3}$.

Regarding the values $8 \mathrm{H}$, Table 7 summarizes the statistical values of $\mathrm{O}_{3}$ concentration observed in the period 2013, which were from 8 to $137 \mu \mathrm{g} / \mathrm{m}^{3}$ with a mean of $37 \mu \mathrm{g} / \mathrm{m}^{3}$ and a standard deviation of $18 \mu \mathrm{g} / \mathrm{m}^{3}$. In 2014 they were from 4 to $148 \mu \mathrm{g} / \mathrm{m}^{3}$ with a mean of $44 \mu \mathrm{g} / \mathrm{m}^{3}$ and standard deviation of $22 \mu \mathrm{g} / \mathrm{m}^{3}$ and finally in the 2015 period they were from 10 to $151 \mu \mathrm{g} / \mathrm{m}^{3}$, with a mean of $52 \mu \mathrm{g} / \mathrm{m}^{3}$ and a standard deviation of $27 \mu \mathrm{g} / \mathrm{m}^{3}$. Comparing hourly values of Figure 5(b) with the HLV of Mexico NOM-020-SSA1-2014 [51] and the EU directive [44], it is observed that they did not exceed the hourly limit values. Comparing the observations in Figure 5(b) with the $8 \mathrm{HLV}$ of Mexico of $137 \mu \mathrm{g} / \mathrm{m}^{3}$ and $100 \mu \mathrm{g} / \mathrm{m}^{3}$ of the WHO, the Mexican standard was exceeded only three times and the WHO 8HLV was exceeded 31 times; in Figure 5(b) the 8HLV of EU of 120 $\mu \mathrm{g} / \mathrm{m}^{3}$ and the NAAQ of $147 \mu \mathrm{g} / \mathrm{m}^{3}$ of USA were exceeded several times in the period analyzed.

As shown in Figure 6 and Figure 7 in hourly, monthly and weekly $\mathrm{O}_{3}$ pattern; maximum values occur between 12:00 to 17:00 and the minimum between five and six o'clock; The weekly pattern shows Mondays, Wednesdays, Saturdays and Sundays with the highest $\mathrm{O}_{3}$ concentration. The hourly and weekly trends correspond to urban traffic and reflect the dynamics of the city. The monthly trend shows April and May having the maximum values, with the minimum value in September. These trends correspond to behavior, jointly caused by the traffic, the dynamics of the capital and the temperature observed in the periods from January to May, whose tendency is to show a rise in the average $\mathrm{O}_{3}$ concentration, and decreases in the months from June to December, as shown in Figure 2 and Table 1. Regarding the observations of $\mathrm{SO}_{2}$ Figure 5(c) shows the values of HA, 8HA, DA and annual concentrations, and Table 7 shows the summary statistics of the pollutant. The HA values were 10,11 and $37 \mu \mathrm{g} / \mathrm{m}^{3}$ with a standard deviation of 4,6 and $16 \mu \mathrm{g} / \mathrm{m}^{3}$. The $8 \mathrm{H}$ and daily mean values were 


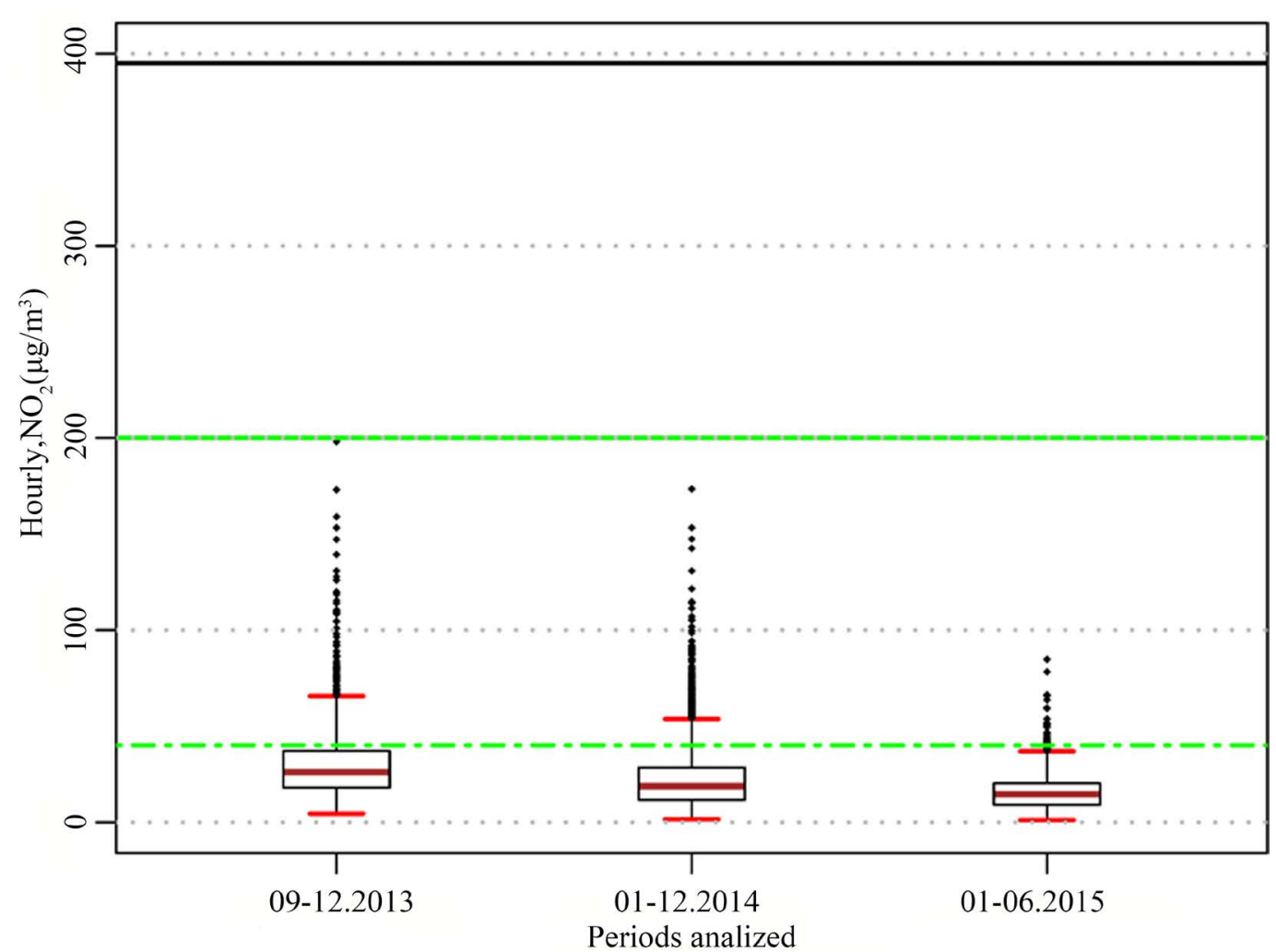

(a)

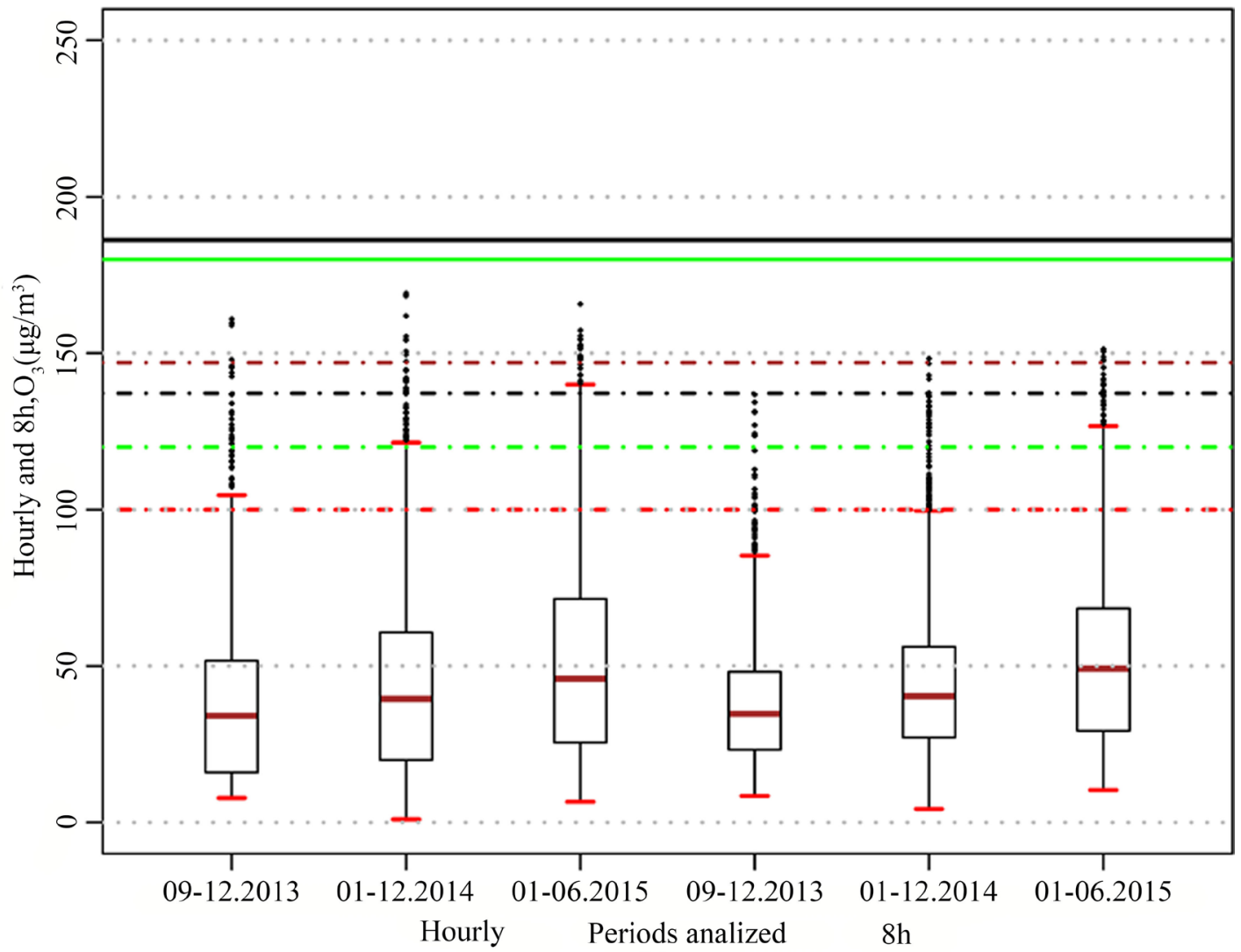

(b) 


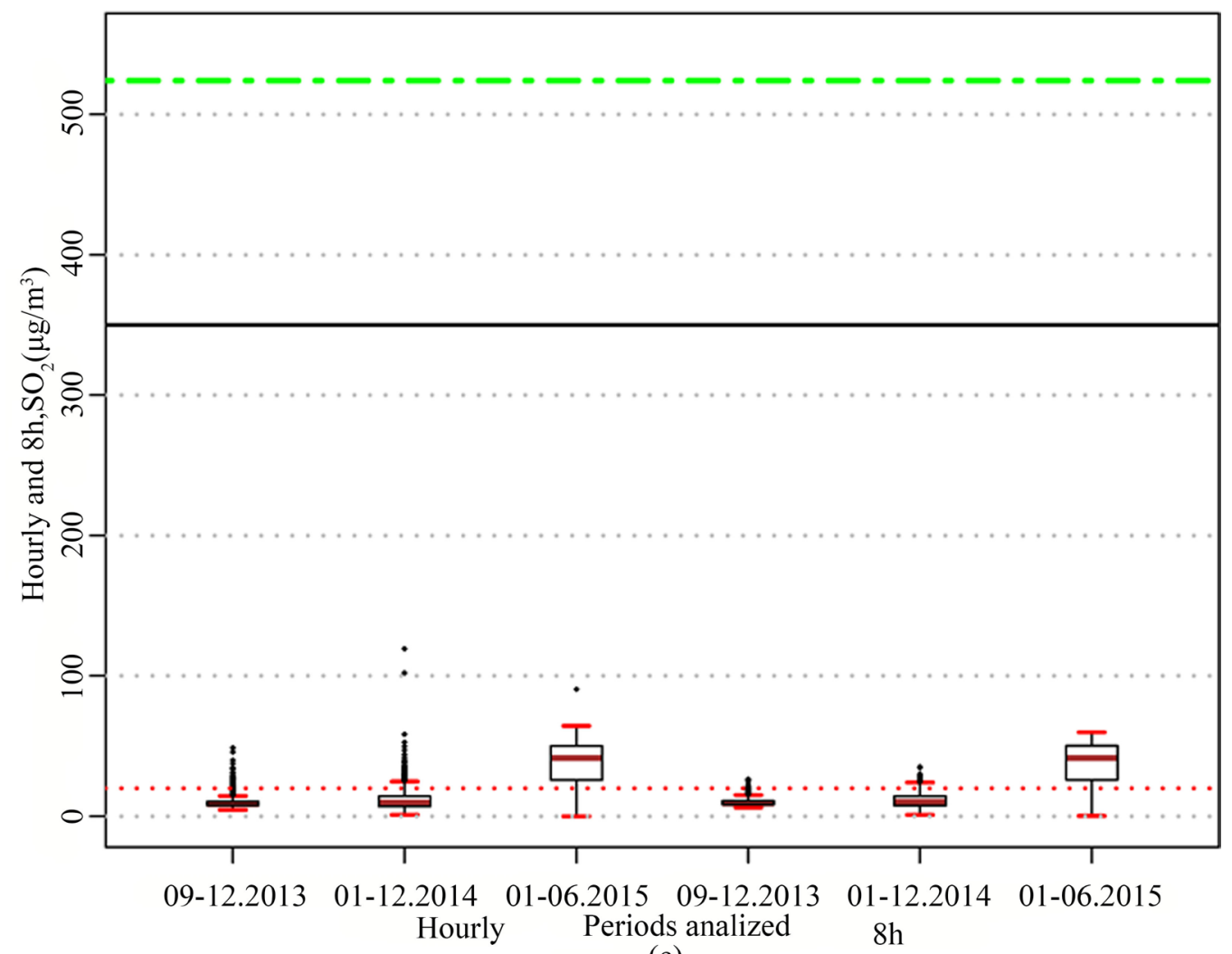

(c)

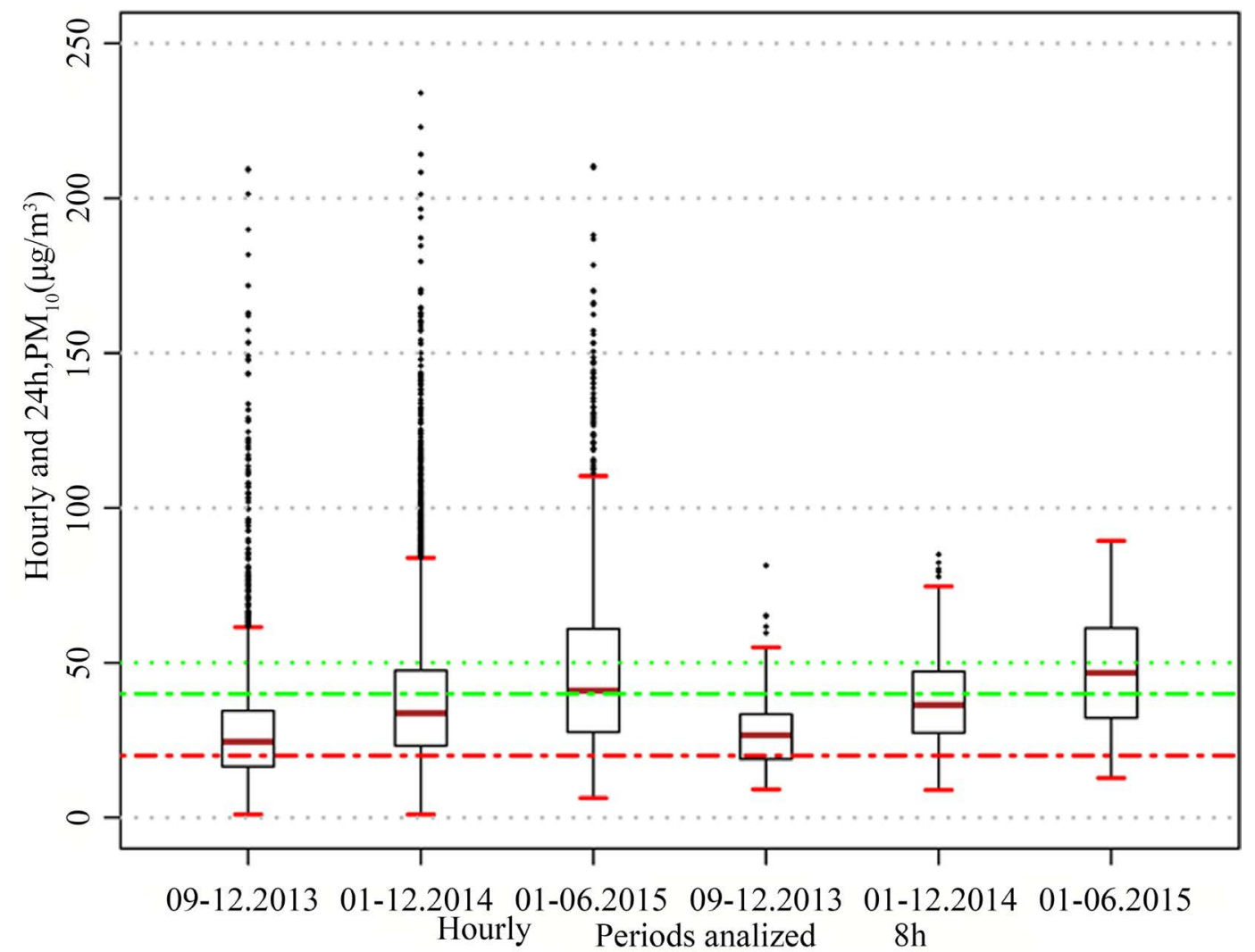

(d) 


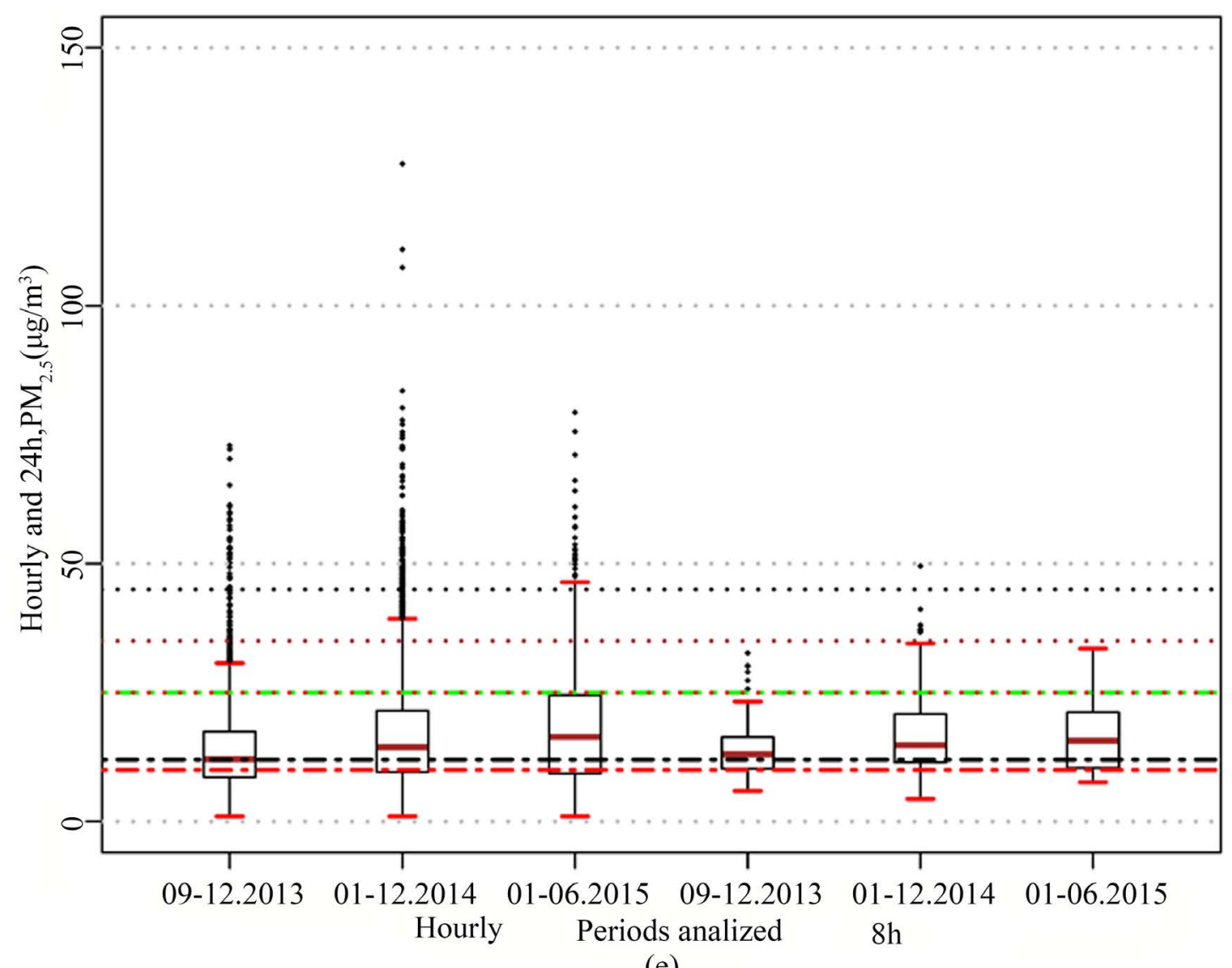

(e)

\begin{tabular}{|c|c|}
\hline \multicolumn{2}{|c|}{$\begin{array}{l}\text { Xalapa AQ Monitoring Station } \\
\text { Period: } 20130901-20150630\end{array}$} \\
\hline ALV Mexico & $-\cdots-$ \\
\hline HLV Mexico & \\
\hline 8HLV Mexico & - \\
\hline DLV Mexico & n................. \\
\hline ALV EU & $-\cdots-$ \\
\hline HLV EU & \\
\hline 8 HLV EU & $-\cdot$ \\
\hline ALV WHO & $-\cdots-$ \\
\hline HLV WHO & \\
\hline DLV WHO & י................ \\
\hline 8HLV NAAQS & $-\cdot-$ \\
\hline DLV NAAQS & •............... \\
\hline
\end{tabular}

Figure 5. $\mathrm{NO}_{2}, \mathrm{O}_{3}, \mathrm{SO}_{2}, \mathrm{PM}_{10}$ and $\mathrm{PM}_{2.5}$ boxplots, the graphics show comparatives between observations and HLV, 8HLV, DLV and ALV standards of Mexico (MX), European Union (EU), NAAQS-USA (NAAQ) and WHO guidelines in Xalapa AQ station. 
Temporal concentration AQ Xalapa station
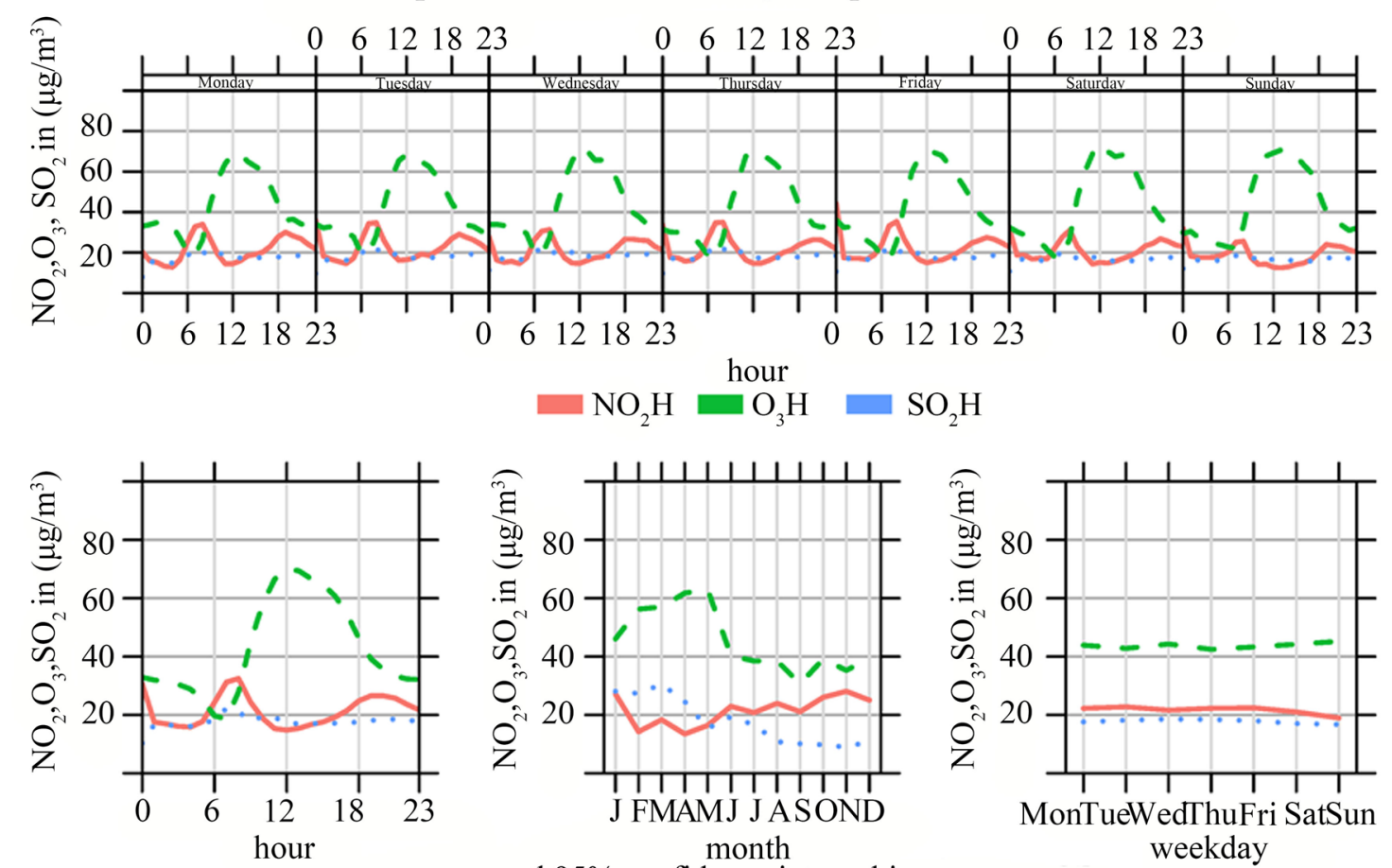

mean and $95 \%$ confidence interval in mean
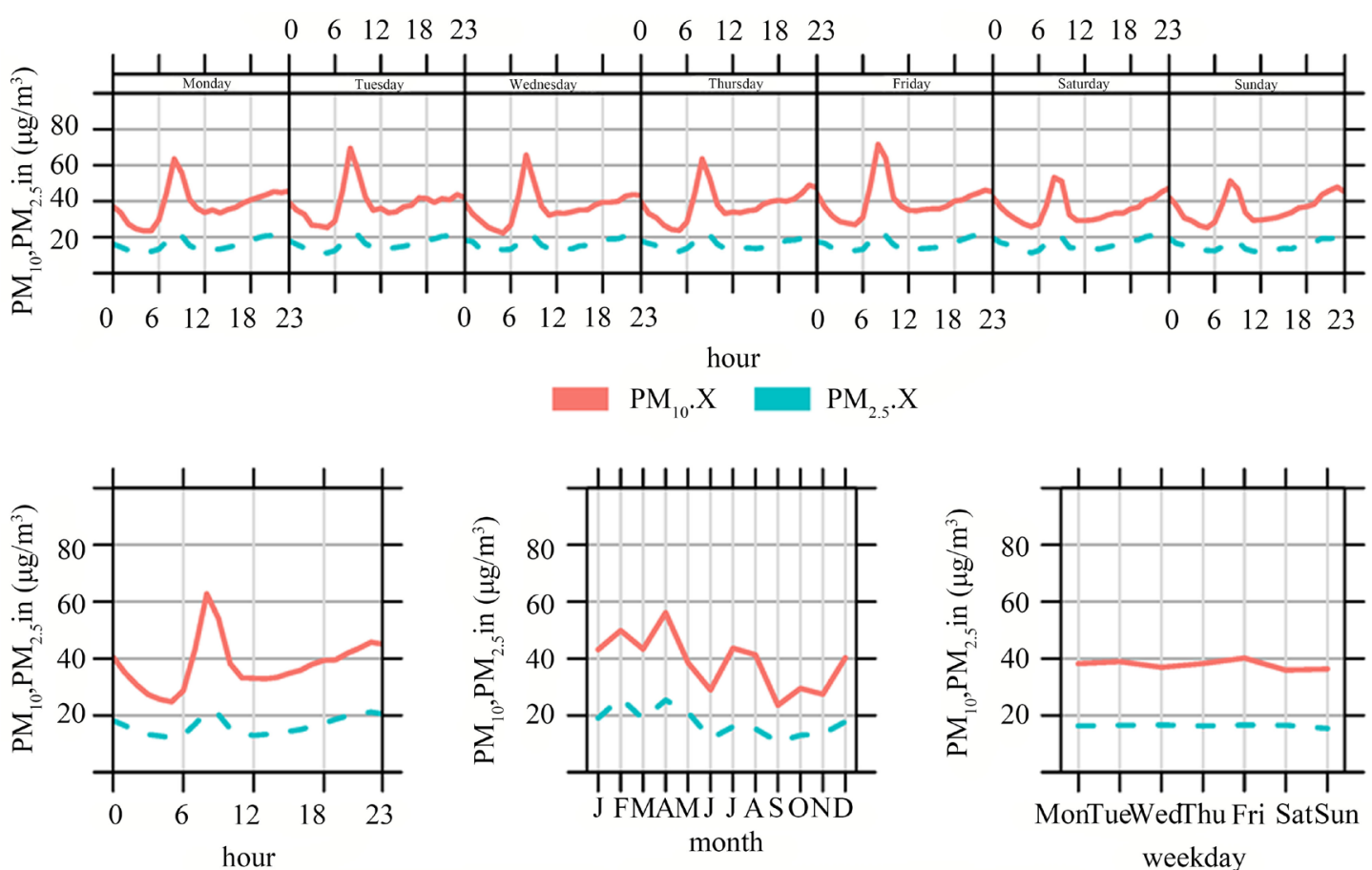

mean and $95 \%$ confidence interval in mean

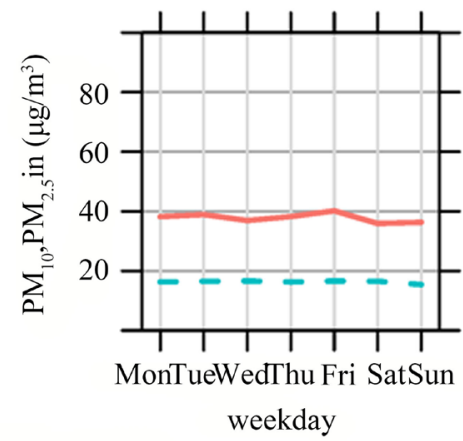

Figure 6. Temporal concentration of $\mathrm{O}_{3}, \mathrm{NO}_{2}, \mathrm{SO}_{2}, \mathrm{PM}_{10}$ and $\mathrm{PM}_{2.5}$ in Xalapa AQ station.

10,11 and $37 \mu \mathrm{g} / \mathrm{m}^{3}$, with a standard deviation of 2,5 and $16 \mu \mathrm{g} / \mathrm{m}^{3}$.

Figure 6 shows that the average levels of $\mathrm{SO}_{2}$ increased hourly between 06:00 to 11:00, showing a trend around $20 \mu \mathrm{g} / \mathrm{m}^{3}$ in the day. When reviewing the pattern, days with average maximum values are Wednesdays 

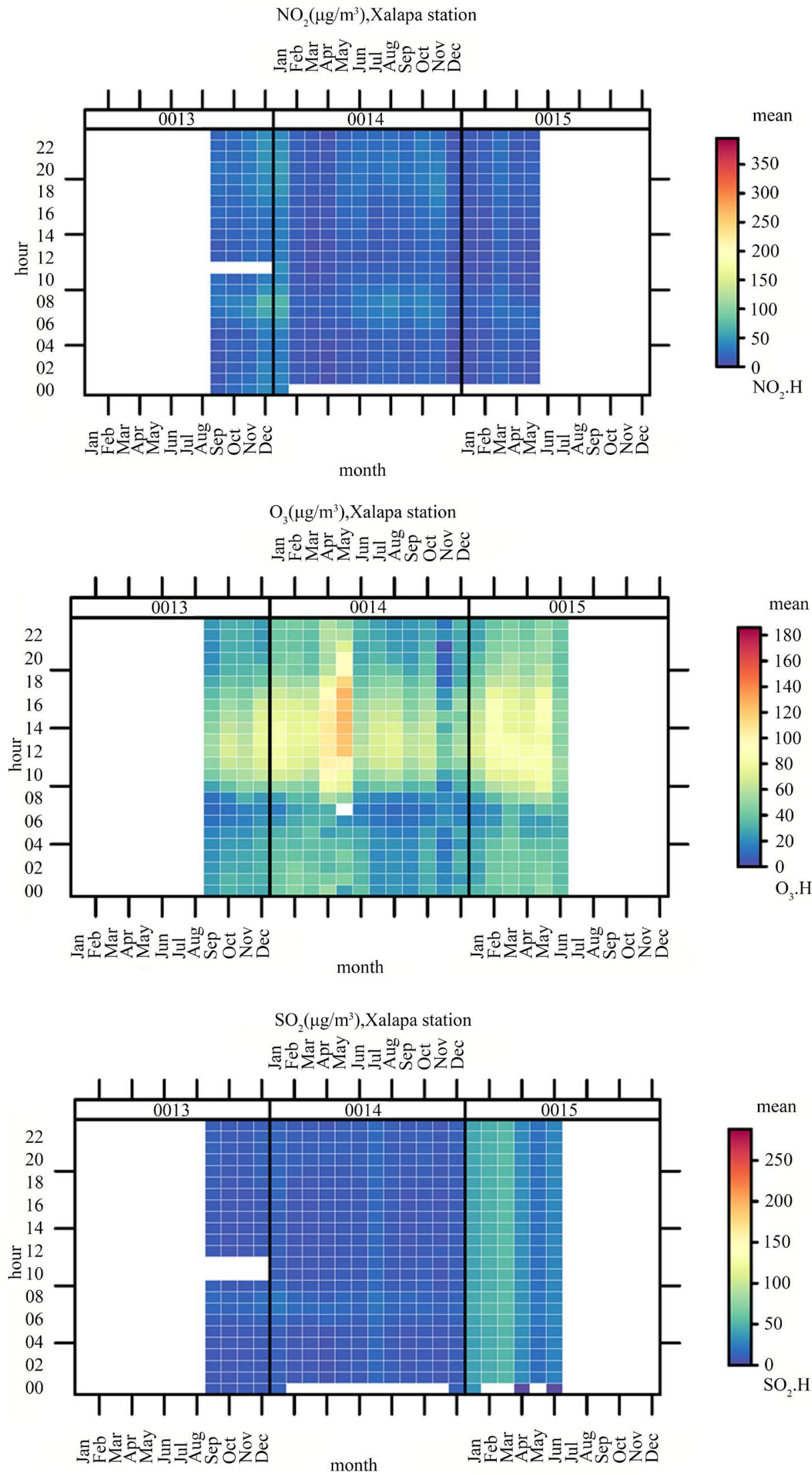


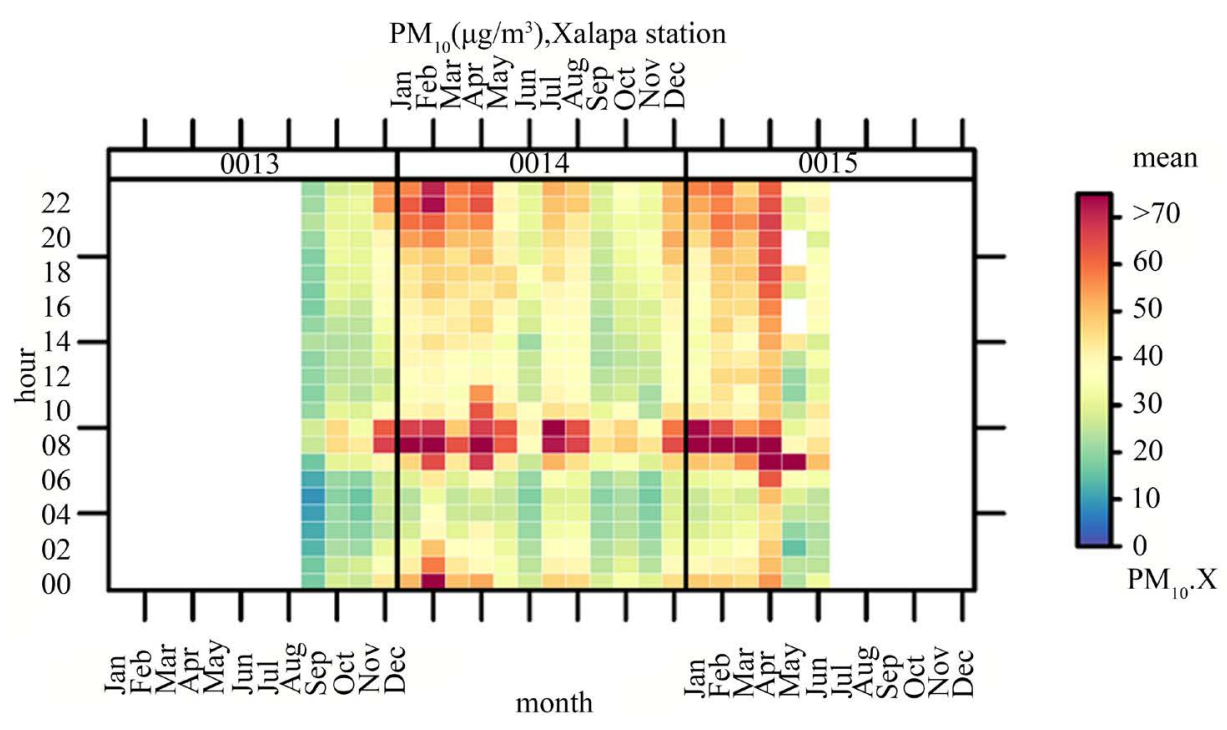

Figure 7. Annual and hourly trends in Xalapa AQ station.

and Thursdays, with a tendency to minimum values at the weekend. Finally, to analyze the monthly pattern, it is seen that the maximum values occur in the months of January, February and March, tending to gradually decrease until November and December, This trend can be attributed to the fact that in the months mentioned in the MZ, as shown in Table 1, rainfall is lower than in the rest of the year, leading to further accumulation of $\mathrm{SO}_{2}$ for the dry winter season. The values and trends for hourly, weekly and monthly observations are consistent with values from an urban traffic station.

According to the NOM-022-SSA1-2010 [52] the value limits of $8 \mathrm{HLV}$ of $524 \mu \mathrm{g} / \mathrm{m}^{3}$, DLV of $288 \mu \mathrm{g} / \mathrm{m}^{3}$ and the ALV of $66 \mu \mathrm{g} / \mathrm{m}^{3}$ were not exceeded; the value limits of the WHO, EU and the NAAQ of USA were not exceeded in the period analyzed. The observations and statistics shown in Figure 5(d) and Table 7 respectively show the values HA, DA and annual $\mathrm{PM}_{10}$ during the period analyzed. The HA values were 29,38 and $47 \mu \mathrm{g} / \mathrm{m}^{3}$ with a standard deviation of 21,23 and $28 \mu \mathrm{g} / \mathrm{m}^{3}$; while the daily average values were 28,38 and $48 \mu \mathrm{g} / \mathrm{m}^{3}$ with a standard deviation of 13,15 and $20 \mu \mathrm{g} / \mathrm{m}^{3}$. In Figure 5(e) of $\mathrm{PM}_{2.5}$, the HA values were 14,17 and $19 \mu \mathrm{g} / \mathrm{m}^{3}$ with a standard deviation of 9,10 and $12 \mu \mathrm{g} / \mathrm{m}^{3}$; and daily average of 14,17 and $17 \mu \mathrm{g} / \mathrm{m}^{3}$ with a standard deviation of 5, 7 and $7 \mu \mathrm{g} / \mathrm{m}^{3}$. In Figure 6 and Figure 7, an analysis of the hourly pattern of $\mathrm{PM}_{10}$ and $\mathrm{PM}_{2.5}$ shows that maximums of $60 \mu \mathrm{g} / \mathrm{m}^{3}$ are reached between 06:00 to 10:00, reducing around noon, and tending to rise to an average value $40 \mu \mathrm{g} / \mathrm{m}^{3}$ from 13:00 to 23:00 and the average minimum is observed between 04:00 to 05:00. In the weekly pattern, the media thresholds are observed on Wednesday, Saturday and Sunday; growth trends occur in two periods, from Monday to Tuesday and from Thursday to Friday. When reviewing the monthly increase, performance trends occur between the months of December to April, showing an intermediate maximum peak between the months of July and August.

The behavior of particulates is partly determined by the hourly and weekly trend in urban traffic patterns in the city, but not only by the passenger traffic of the city itself: the location experiences a high volume of transport cargo crossing the city that uses diesel fuel. Other sources may be areas close to the MZ under erosion by growing urban area and also surrounded by waste burning that takes place in the nearby farming areas, a process used by farmers in the area. Other sources may be seasonal, for example, winter months favoring the increase of secondary particles such as ammonium nitrate. Comparing $\mathrm{PM}_{10}$ observations with Mexican regulations, NOM025-SSA1-2014 [53], the DLV of $75 \mu \mathrm{g} / \mathrm{m}^{3}$ was exceeded 12 times; the ALV of $40 \mu \mathrm{g} / \mathrm{m}^{3}$ was also exceeded in the period of analysis. WHO DLV of $50 \mu \mathrm{g} / \mathrm{m}^{3}$ and ALV of $20 \mu \mathrm{g} / \mathrm{m}^{3}$ were exceeded more often. Regarding the $\mathrm{PM}_{2.5}$, the daily $45 \mu \mathrm{g} / \mathrm{m}^{3}$ and annual $12 \mu \mathrm{g} / \mathrm{m}^{3}$ Mexican regulations limit values were also exceeded several times, although a number of observations were lost for various reasons. The WHO DLV of $25 \mu \mathrm{g} / \mathrm{m}^{3}$ and ALV of $10 \mu \mathrm{g} / \mathrm{m}^{3}$, the ALV of EU of $12 \mu \mathrm{g} / \mathrm{m}^{3}$ and the USA-NAAQ $35 \mu \mathrm{g} / \mathrm{m}^{3}$ were also exceeded.

\subsection{Minatitlan Air Quality Station}

Figure 8(a) presents the observations of the urban traffic-fixed station by its proximity to industrial sources; the 
Table7. Statistical summary of pollutants measurement from Xalapa monitoring station from 01.09.2013-30.06.2015.

\begin{tabular}{|c|c|c|c|c|c|c|c|c|}
\hline \multirow{2}{*}{ Period } & \multicolumn{8}{|c|}{ Pollutants concentrations $\left(\mu \mathrm{g} / \mathrm{m}^{3}\right)$} \\
\hline & Pollutant & Min & $1^{\text {st }} \mathrm{Qu}$ & Median & Mean & $3^{\text {rd }} \mathrm{Qu}$. & Max & SD \\
\hline 09-12.2013 & $\mathrm{NO}_{2}-\mathrm{H}$ & 4.0 & 18.00 & 26.00 & 30.00 & 37.00 & 198.00 & 19.00 \\
\hline 01-12.2014 & & 2.00 & 12.00 & 19.00 & 22.00 & 29.00 & 173.00 & 15.00 \\
\hline 01-06.2015 & & 1.00 & 9.00 & 15.00 & 15.00 & 20.00 & 85.00 & 9.00 \\
\hline 09-12.2013 & $\mathrm{NO}_{2}-\mathrm{A}$ & 4.00 & 18.00 & 26.00 & 30.00 & 37.00 & 198.00 & NC \\
\hline 01-12.2014 & & 2.00 & 12.00 & 19.00 & 22.00 & 29.00 & 173.00 & NC \\
\hline 01-06.2015 & & 1.00 & 9.00 & 15.00 & 15.00 & 20.00 & 85.00 & NC \\
\hline 09-12.2013 & $\mathrm{O}_{3}-\mathrm{H}$ & 8.00 & 16.00 & 34.00 & 37.00 & 52.00 & 161.00 & 24.00 \\
\hline 01-12.2014 & & 1.00 & 20.00 & 40.00 & 43.00 & 61.00 & 169.00 & 27.00 \\
\hline 01-06.2015 & & 7.00 & 26.00 & 46.00 & 51.00 & 71.00 & 166.00 & 31.00 \\
\hline 09-12.2013 & $\mathrm{O}_{3} 8 \mathrm{H}$ & 8.00 & 23.00 & 35.00 & 37.00 & 48.00 & 138.00 & 18.00 \\
\hline 01-12.2014 & & 4.00 & 27.00 & 40.00 & 44.00 & 56.00 & 148.00 & 22.00 \\
\hline 01-06.2015 & & 10.00 & 29.00 & 49.00 & 52.00 & 68.00 & 151.00 & 27.00 \\
\hline 09-12.2013 & $\mathrm{SO}_{2}-\mathrm{H}$ & 5.00 & 8.00 & 9.00 & 10.00 & 10.00 & 49.00 & 4.00 \\
\hline 01-12.2014 & & 1.00 & 7.00 & 10.00 & 11.00 & 14.00 & 119.00 & 6.00 \\
\hline 01-06.2015 & & 0.00 & 26.00 & 42.00 & 37.00 & 50.00 & 91.00 & 16.00 \\
\hline 09-12.2013 & $\mathrm{SO}_{2}-8 \mathrm{H}$ & 6.00 & 8.00 & 9.00 & 10.00 & 11.00 & 26.00 & 2.00 \\
\hline $01-12.2014$ & & 1.00 & 8.00 & 10.00 & 11.00 & 14.00 & 35.00 & 5.00 \\
\hline 01-06.2015 & & 0.00 & 26.00 & 42.00 & 37.00 & 50.00 & 60.00 & 16.00 \\
\hline 09-12.2013 & $\mathrm{SO}_{2}-\mathrm{D}$ & 7.00 & 9.00 & 10.00 & 10.00 & 11.00 & 17.00 & 2.00 \\
\hline $01-12.2014$ & & 3.00 & 8.00 & 10.00 & 11.00 & 14.00 & 29.00 & 5.00 \\
\hline 01-06.2015 & & 2.00 & 26.00 & 41.00 & 37.00 & 50.00 & 57.00 & 16.00 \\
\hline 09-12.2013 & $\mathrm{PM}_{10}-\mathrm{H}$ & 1.00 & 17.00 & 25.00 & 29.00 & 35.00 & 210.00 & 21.00 \\
\hline 01-12.2014 & & 1.00 & 23.00 & 34.00 & 38.00 & 48.00 & 234.00 & 23.00 \\
\hline 01-06.2015 & & 6.00 & 28.00 & 41.00 & 48.00 & 61.00 & 211.00 & 28.00 \\
\hline 09-12.2013 & $\mathrm{PM}_{10}-\mathrm{D}$ & 9.00 & 19.00 & 27.00 & 28.00 & 33.00 & 81.00 & 13.00 \\
\hline 01-12.2014 & & 9.00 & 27.00 & 36.00 & 38.00 & 47.00 & 85.00 & 15.00 \\
\hline 01-06.2015 & & 13.00 & 32.00 & 47.00 & 48.00 & 61.00 & 89.00 & 20.00 \\
\hline 09-12.2013 & $\mathrm{PM}_{2.5}-\mathrm{H}$ & 1.00 & 9.00 & 12.00 & 14.00 & 18.00 & 73.00 & 9.00 \\
\hline $01-12.2014$ & & 1.00 & 10.00 & 15.00 & 17.00 & 22.00 & 128.00 & 10.00 \\
\hline 01-06.2015 & & 1.00 & 9.00 & 16.00 & 19.00 & 25.00 & 79.00 & 12.00 \\
\hline 09-12.2013 & $\mathrm{PM}_{2.5}-\mathrm{D}$ & 6.00 & 10.00 & 13.00 & 14.00 & 16.00 & 34.00 & 5.00 \\
\hline $01-12.2014$ & & 4.00 & 12.00 & 15.00 & 17.00 & 21.00 & 50.00 & 7.00 \\
\hline 01-06.2015 & & 7.60 & 10.60 & 15.70 & 17.00 & 22.00 & 34.00 & 7.00 \\
\hline
\end{tabular}

NC: Not calculated. 
mean values of $\mathrm{NO}_{2}$ concentration of 14,17 and $9 \mu \mathrm{g} / \mathrm{m}^{3}$, and a standard deviation of 13,17 and $10 \mu \mathrm{g} / \mathrm{m}^{3}$ in the respective periods. Table 8 shows HA values ranging from 0 to $220 \mu \mathrm{g} / \mathrm{m}^{3}$. Most observations did not exceed $100 \mu \mathrm{g} / \mathrm{m}^{3}$.

Table 8. Statistical summary of pollutants measurement from Minatitlan monitoring station from 01.09.2013-30.06.2015.

\begin{tabular}{|c|c|c|c|c|c|c|c|c|}
\hline \multirow{2}{*}{ Period } & \multicolumn{8}{|c|}{ Pollutants concentrations $\left(\mu \mathrm{g} / \mathrm{m}^{3}\right)$} \\
\hline & Pollutant & Min & $1^{\text {st }} \mathrm{Qu}$. & Median & Mean & $3^{\text {rd }} \mathrm{Qu}$. & Max & SD \\
\hline 09-12.2013 & $\mathrm{NO}_{2}-\mathrm{H}$ & 1 & 5.27 & 9.97 & 13.61 & 18.44 & 212.90 & 13.00 \\
\hline 01-12.2014 & & 1.00 & 6.00 & 12.00 & 17.00 & 22.00 & 220.00 & 17.00 \\
\hline 01-06.2015 & & 0.00 & 3.00 & 6.00 & 9.00 & 10.00 & 135.00 & 10.00 \\
\hline 09-12.2013 & $\mathrm{NO}_{2}-\mathrm{A}$ & 1.00 & 5.00 & 10.00 & 14.00 & 19.00 & 220.00 & NC \\
\hline 01-12.2014 & & 1.00 & 6.00 & 12.00 & 17.00 & 22.00 & 220.00 & NC \\
\hline 01-06.2015 & & 0.00 & 3.00 & 6.00 & 9.00 & 10.00 & 135.00 & NC \\
\hline 09-12.2013 & $\mathrm{O}_{3}-\mathrm{H}$ & 3.00 & 35.00 & 57.00 & 58.00 & 79.00 & 208.00 & 29.00 \\
\hline 01-12.2014 & & 2.00 & 30.00 & 47.00 & 51.00 & 65.00 & 240.00 & 29.00 \\
\hline 01-06.2015 & & 2.00 & 27.00 & 43.00 & 46.00 & 62.00 & 223.00 & 26.00 \\
\hline 09-12.2013 & $\mathrm{O}_{3} 8 \mathrm{H}$ & 7.00 & 39.00 & 57.00 & 58.00 & 76.00 & 151.00 & 24.00 \\
\hline $01-12.2014$ & & 2.00 & 35.00 & 48.00 & 52.00 & 63.00 & 160.00 & 24.00 \\
\hline 01-06.2015 & & 4.00 & 31.00 & 44.00 & 46.00 & 59.00 & 146.00 & 21.00 \\
\hline 09-12.2013 & $\mathrm{SO}_{2}-\mathrm{H}$ & 3.00 & 7.00 & 9.00 & 15.00 & 13.00 & 276.00 & 23.00 \\
\hline 01-12.2014 & & 2.00 & 12.00 & 32.00 & 34.00 & 37.00 & 452.00 & 34.00 \\
\hline 01-06.2015 & & 0.00 & 35.00 & 37.00 & 46.00 & 42.00 & 385.00 & 30.00 \\
\hline 09-12.2013 & $\mathrm{SO}_{2}-8 \mathrm{H}$ & 4.00 & 7.00 & 10.00 & 15.00 & 16.00 & 108.00 & 14.00 \\
\hline 01-12.2014 & & 3.00 & 16.00 & 34.00 & 34.00 & 41.00 & 244.00 & 22.00 \\
\hline 01-06.2015 & & 8.00 & 36.00 & 39.00 & 45.00 & 47.00 & 232.00 & 17.00 \\
\hline 09-12.2013 & $\mathrm{SO}_{2}-\mathrm{D}$ & 5.00 & 9.00 & 12.00 & 15.00 & 19.00 & 45.00 & 9.00 \\
\hline 01-12.2014 & & 5.00 & 21.00 & 35.00 & 34.00 & 44.00 & 123.00 & 17.00 \\
\hline 01-06.2015 & & 33.00 & 37.00 & 42.00 & 45.00 & 50.00 & 74.00 & 10.00 \\
\hline 09-12.2013 & $\mathrm{PM}_{10}-\mathrm{H}$ & 2.00 & 21.00 & 33.00 & 38.00 & 50.0 & 187.00 & 23.00 \\
\hline $01-12.2014$ & & 2.00 & 25.00 & 35.00 & 39.00 & 48.00 & 192.00 & 20.00 \\
\hline 01-06.2015 & & 2.00 & 21.00 & 30.00 & 38.00 & 46.00 & 269.00 & 28.00 \\
\hline 09-12.2013 & $\mathrm{PM}_{10}-\mathrm{D}$ & 10.50 & 22.00 & 37.00 & 38.50 & 47.70 & 86.40 & 19.00 \\
\hline 01-12.2014 & & 14.60 & 30.00 & 37.50 & 40.00 & 45.80 & 94.40 & 13.00 \\
\hline 01-06.2015 & & 14.00 & 20.30 & 35.00 & 38.50 & 50.50 & 83.00 & 19.00 \\
\hline 09-12.2013 & $\mathrm{PM}_{2.5}-\mathrm{H}$ & 1.00 & 9.00 & 18.00 & 22.90 & 31.00 & 144.00 & 11.00 \\
\hline $01-12.2014$ & & 1.00 & 9.00 & 15.00 & 19.50 & 25.00 & 181.00 & 10.00 \\
\hline 01-06.2015 & & 1.00 & 5.00 & 9.00 & 13.28 & 17.00 & 113.00 & 13.00 \\
\hline $09-12.2013$ & $\mathrm{PM}_{2.5}-\mathrm{D}$ & 6.80 & 13.70 & 22.00 & 23.00 & 30.40 & 48.00 & 11.00 \\
\hline 01-12.2014 & & 5.20 & 12.60 & 17.10 & 19.40 & 23.10 & 61.20 & 10.00 \\
\hline 01-06.2015 & & 6.00 & 6.50 & 11.00 & 13.00 & 15.00 & 30.00 & 8.00 \\
\hline
\end{tabular}

NC: Not calculated. 


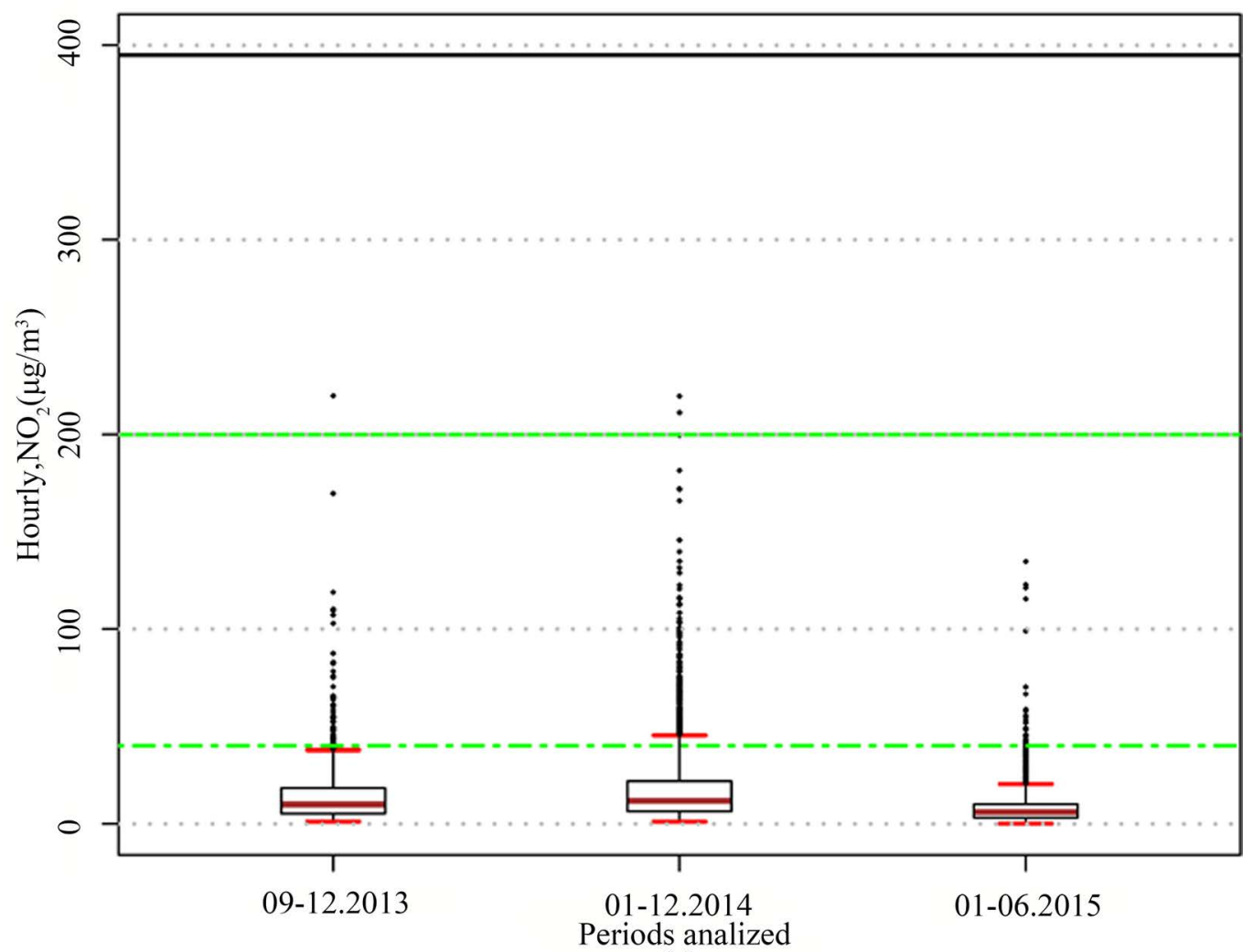

(a)

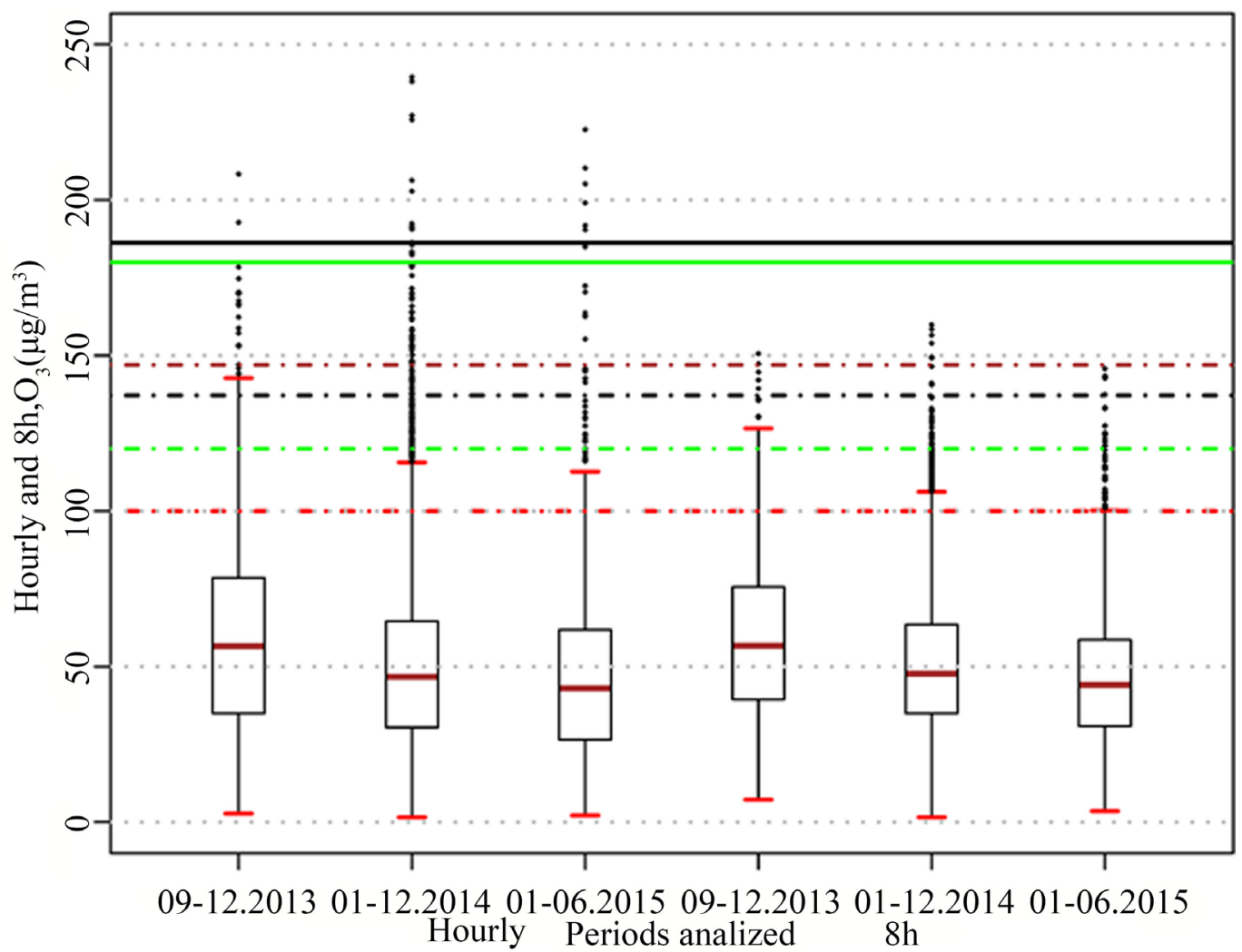

(b) 


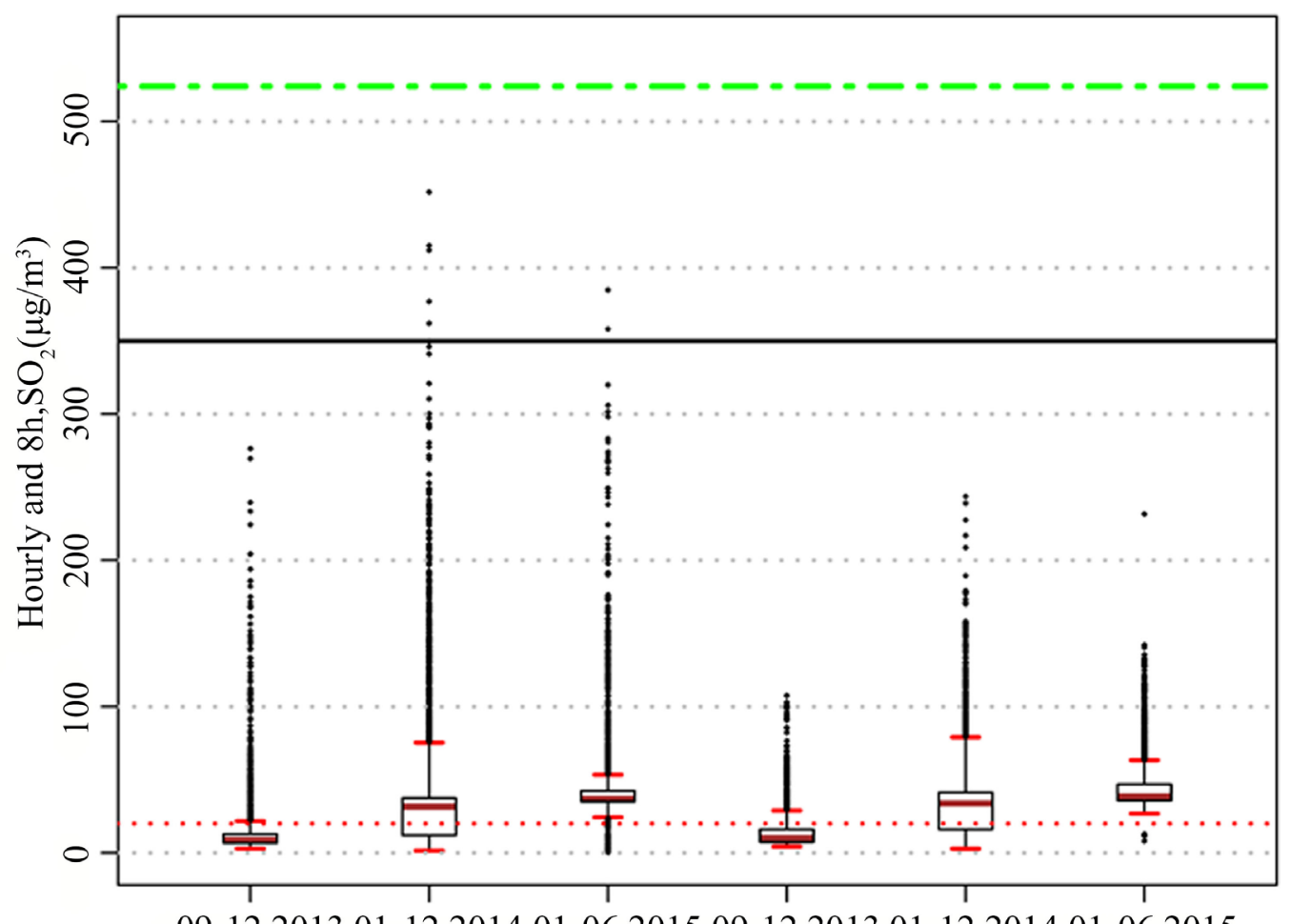

09-12.2013 01-12.2014 01-06.2015 09-12.2013 01-12.2014 01-06.2015

Hourly Periods analized $8 \mathrm{~h}$

(c)

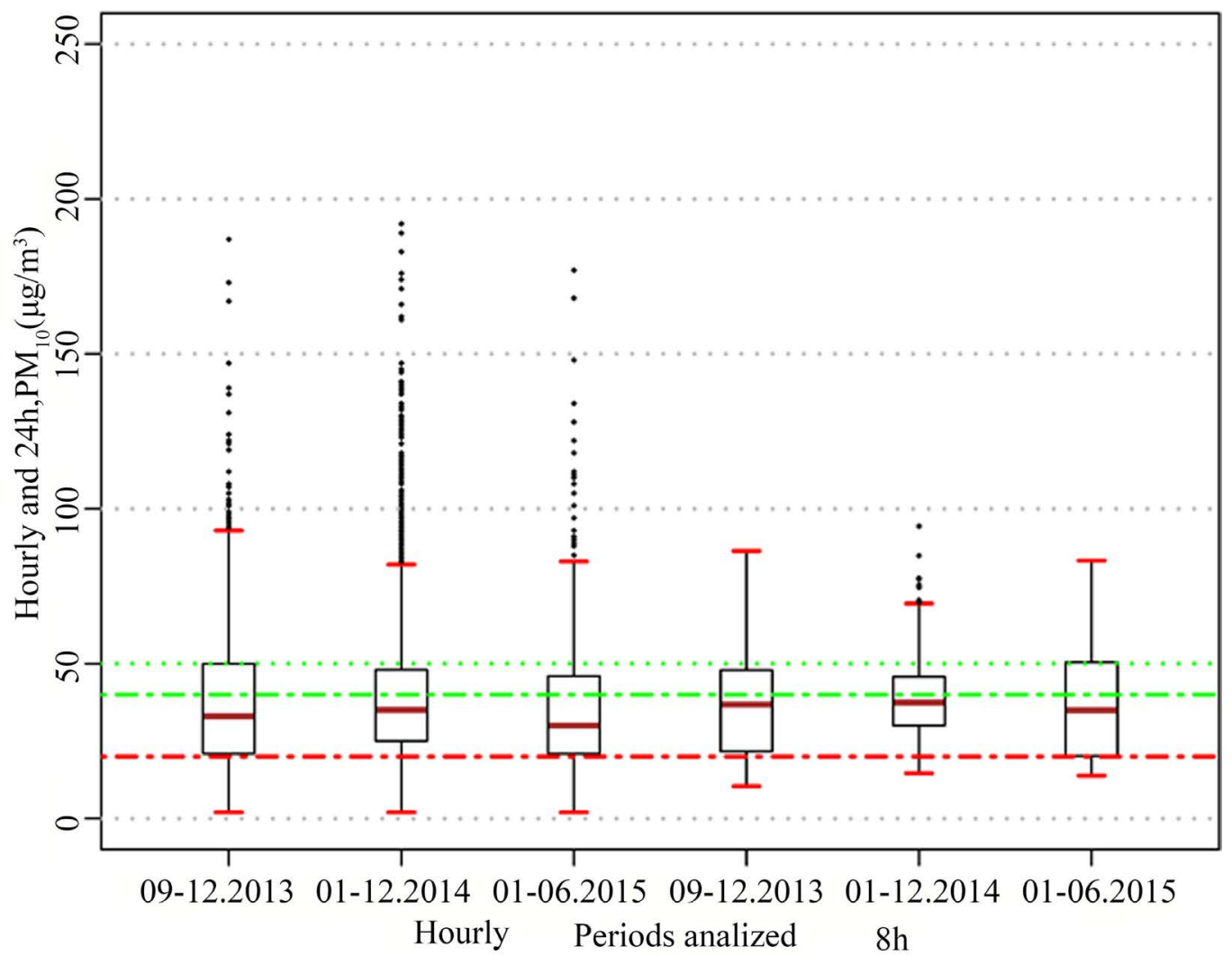

(d) 


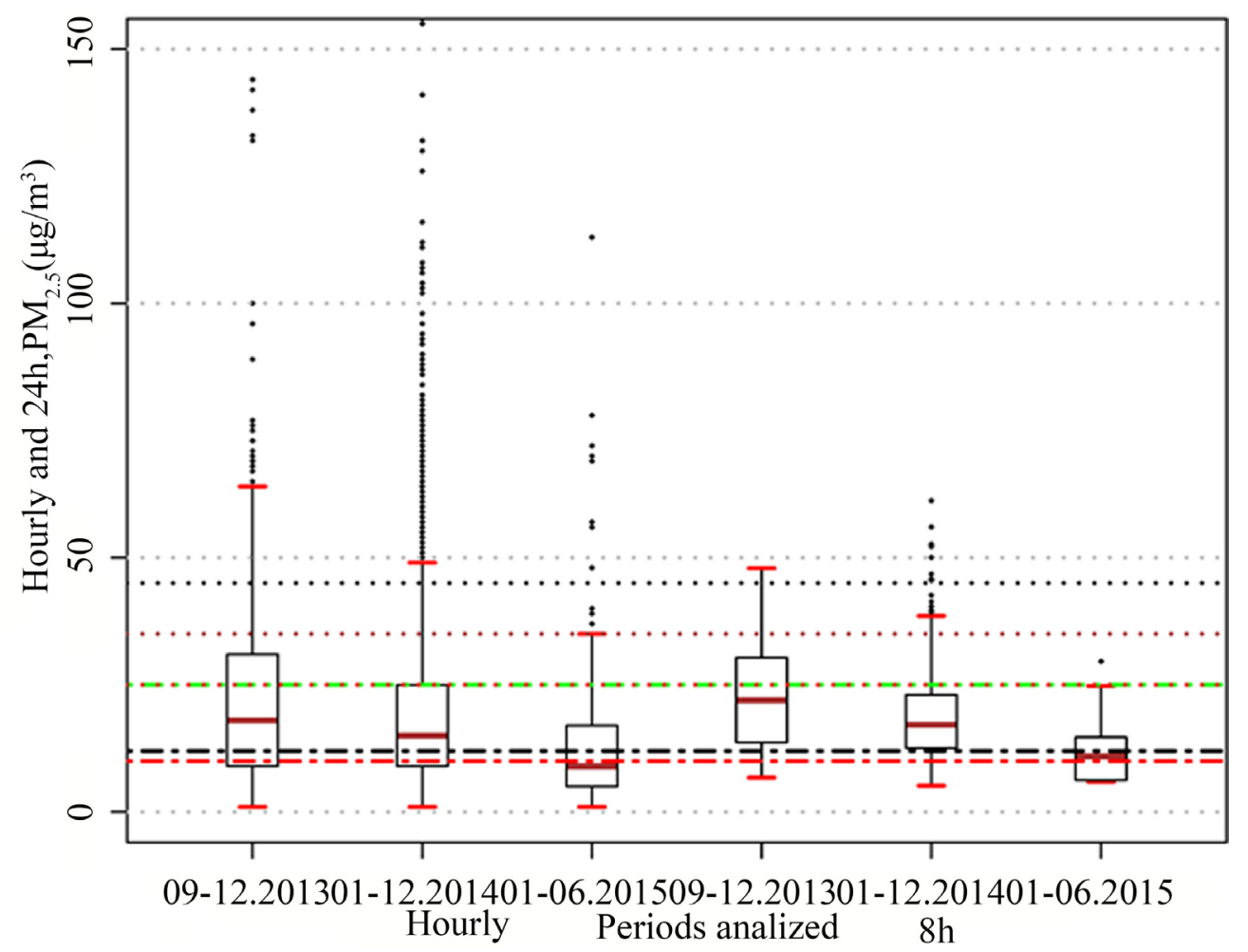

(e)

\begin{abstract}
Figure 8. $\mathrm{NO}_{2}, \mathrm{O}_{3}, \mathrm{SO}_{2}, \mathrm{PM}_{10}$ and $\mathrm{PM}_{2.5}$ boxplots, the graphics show comparatives between observations and HLV, 8HLV, DLV and ALV standards of Mexico (MX), European Union (EU), NAAQSUSA (NAAQ) and WHO guidelines in Minatitlan AQ station.
\end{abstract}

Hourly, $\mathrm{NO}_{2}$ pattern shown in Figure 9 and Figure 10 indicates that from 17:00 to 07:00 an incremental trend reaches an average of $20 \mu \mathrm{g} / \mathrm{m}^{3}$ and decreases between 08:00 to $17: 00$ to $9 \mu \mathrm{g} / \mathrm{m}^{3}$. When reviewing the weekly trend, Wednesday, Thursday, Saturday and Sunday have the minimum average values and Monday and Thursday the highest values. Regarding observed monthly trends, minimum average values are experienced from January to May, increasing from June to December, with a peak in August with an average of $20 \mu \mathrm{g} / \mathrm{m}^{3}$.

The hourly trends are in accordance with the traffic behavior near the station, because of the high concentration of vehicles for industrial activities, urban and private transport. The weekly pattern shows the trend of cargo traffic flow on Mondays, Tuesdays and Fridays. The monthly pattern shows that in the corresponding months of summer and autumn the increase in the concentration of the contaminant is favored. This may be because of temperature and solar radiation in the area, see Figure 3 and Table 2, while in the winter and spring the values decrease by temperature and winds from the north and northeast blow, thus favoring the $\mathrm{NO}_{2}$ dispersion.

Comparing the concentration levels with NOM-023-SSA1-1993, the EU directive and WHO guidance for health in Figure 8(a), the HLV of $200 \mu \mathrm{g} / \mathrm{m}^{3}$ from the EU was exceeded at least six times. The Mexican standard of $395 \mu \mathrm{g} / \mathrm{m}^{3}$ was not exceeded during the period analyzed. Comparing the EU and WHO ALV of 40 $\mu \mathrm{g} / \mathrm{m}^{3}$ with station values. It can be observed that in all the periods this ALV is above both limit values. This value limit does not officially exist in Mexico. Figure 8(b) and Table 8 show the statistics and HA and 8H observations of $\mathrm{O}_{3}$ in the analyzed period. The HA values were 58,51 and $46 \mu \mathrm{g} / \mathrm{m}_{3}$ with a standard deviation of 29,29 and $26 \mu \mathrm{g} / \mathrm{m}^{3}$. The $8 \mathrm{HA}$ values were 58,52 and $46 \mu \mathrm{g} / \mathrm{m}^{3}$ with standard deviation of 24,24 and $21 \mu \mathrm{g} / \mathrm{m}^{3}$ res-pectively.

The trends in Figure 9 and Figure 10 in hourly behaviour show that the minimum average values are given about $06: 00\left(23 \mu \mathrm{g} / \mathrm{m}^{3}\right)$ and from 07:00 the $\mathrm{O}_{3}$ concentration increases to an average concentration of $75 \mu \mathrm{g} / \mathrm{m}^{3}$ at 13:00. When reviewing the weekly trend, the days with the lowest concentration are Monday and Tuesday, increasing slightly and remaining around $51 \mu \mathrm{g} / \mathrm{m}^{3}$ between Thursday and Sunday. The monthly pattern shows two peaks in May and September, holding constant in the other months at around $50 \mu \mathrm{g} / \mathrm{m}^{3}$. This pattern may be 
Temporal concentration AQ minatitlan station
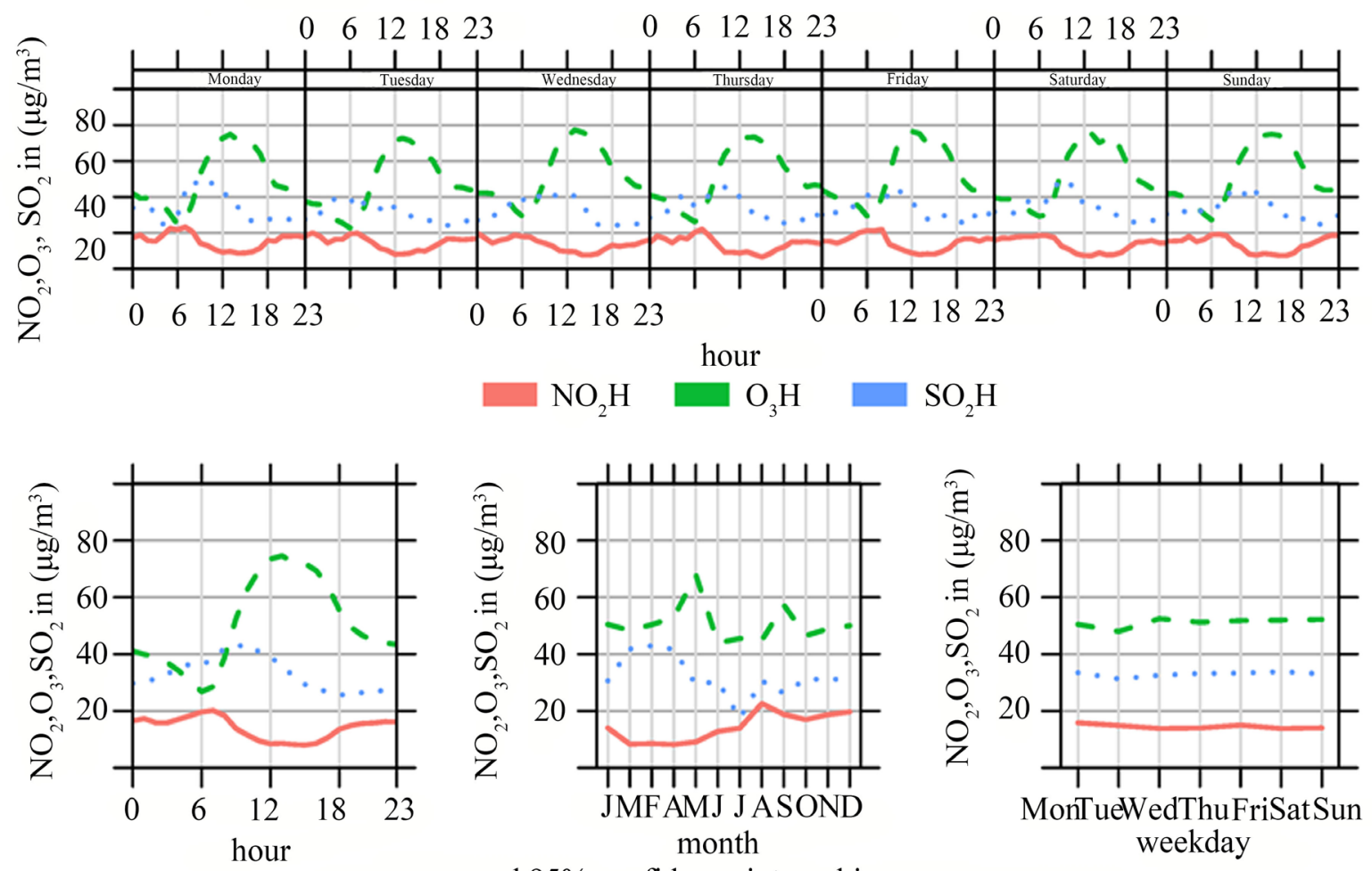

mean and $95 \%$ confidence interval in mean
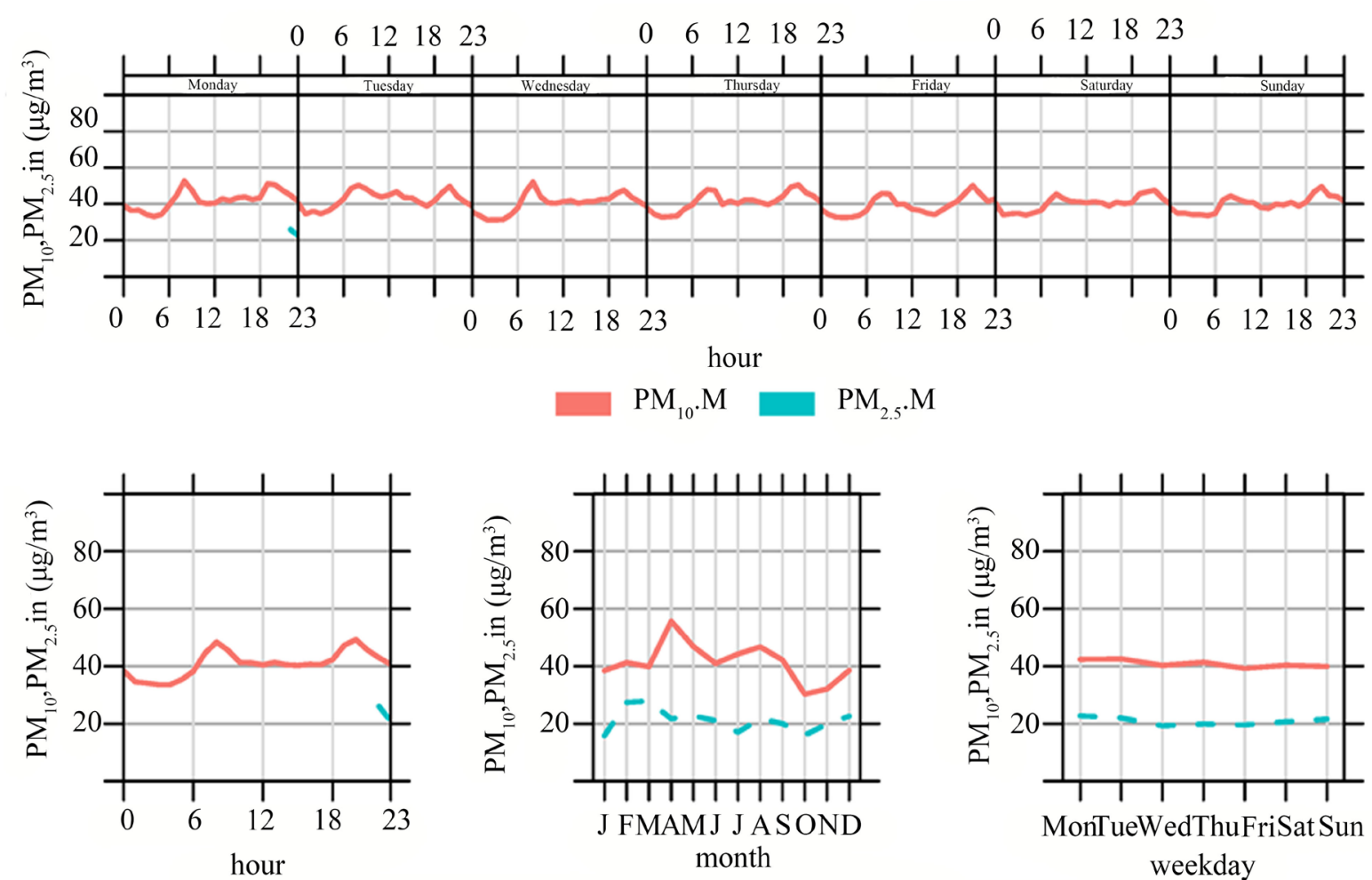

mean and 95\% confidence interval in mean

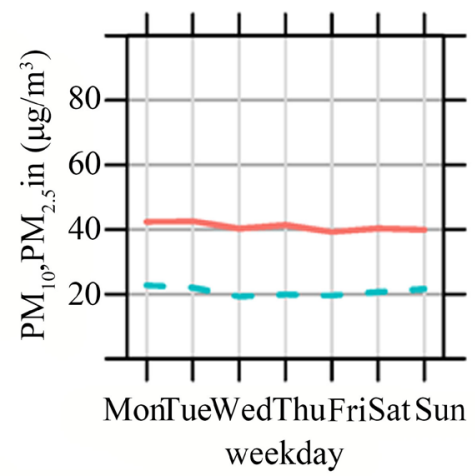

Figure 9. Temporal concentrations of $\mathrm{O}_{3}, \mathrm{NO}_{2}, \mathrm{SO}_{2}, \mathrm{PM}_{10}$ and $\mathrm{PM}_{2.5}$ in Minatitlan AQ station. 

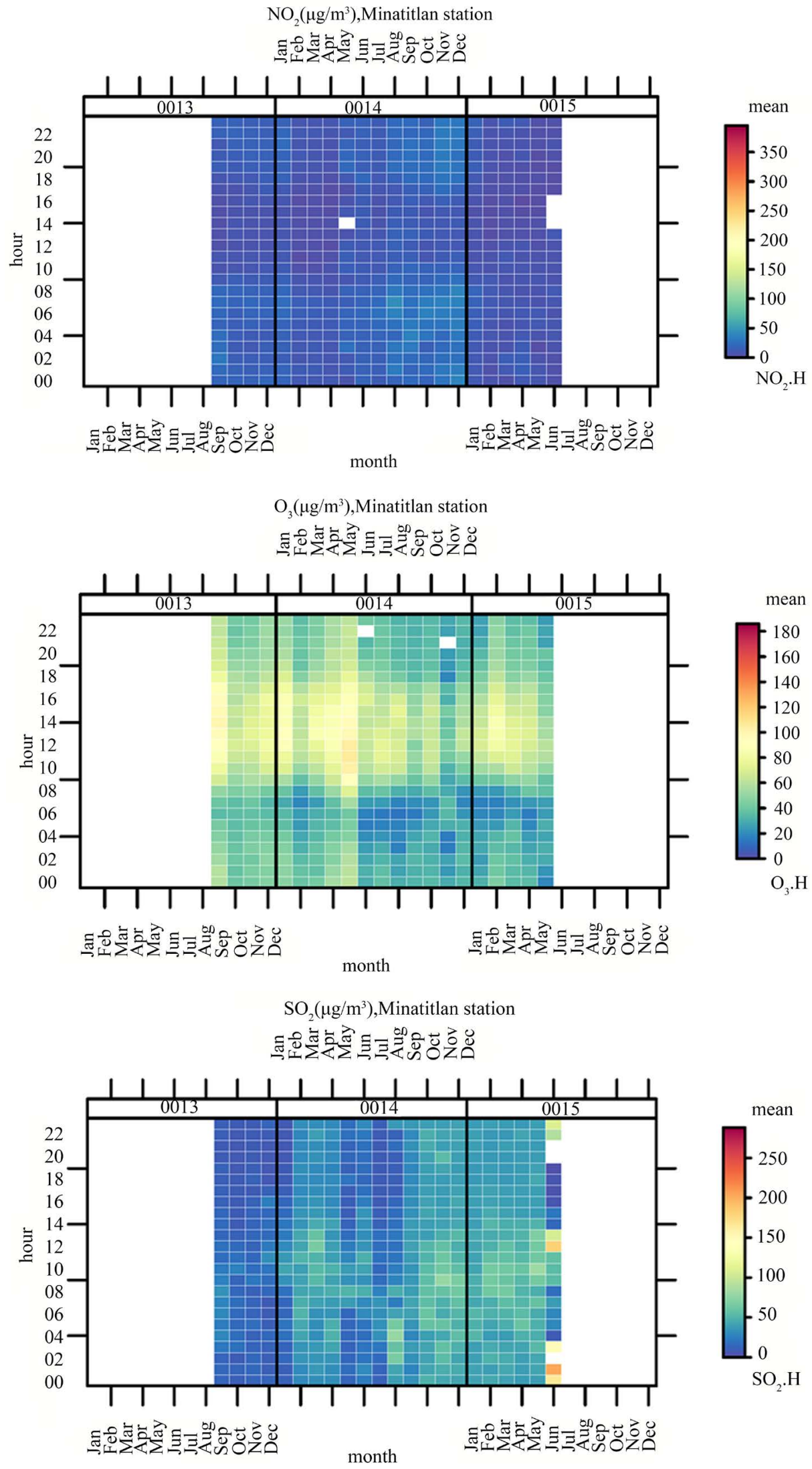


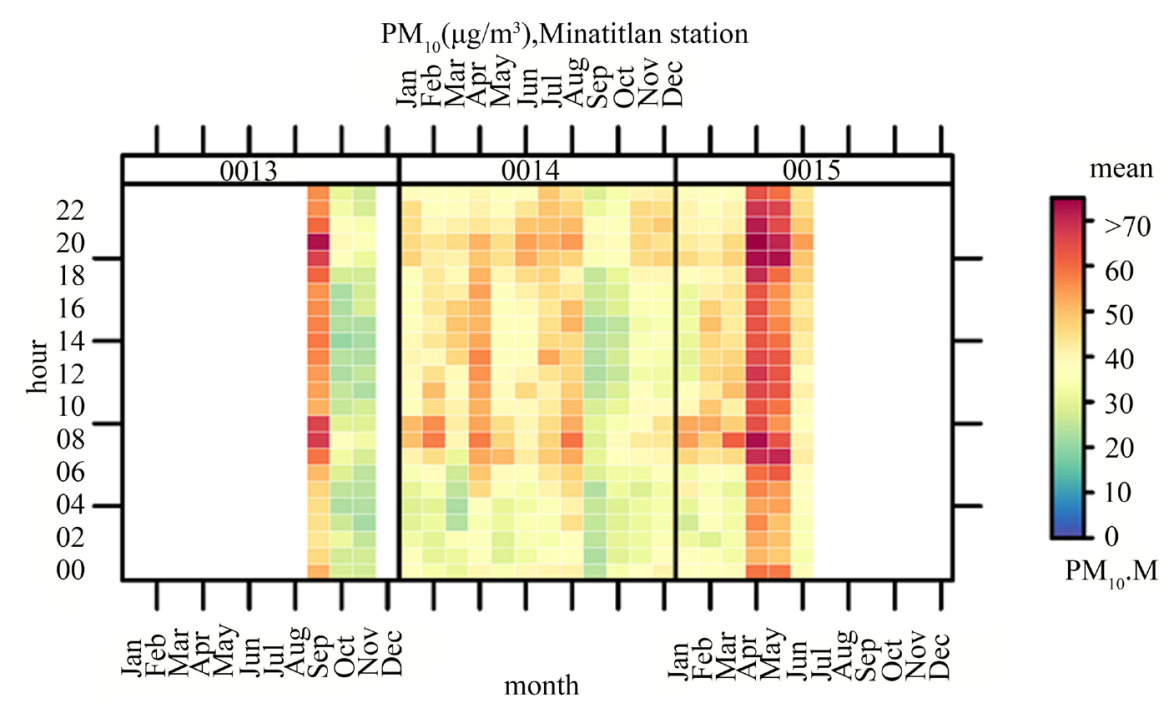

Figure 10. Annual and hourly trends in Minatitlan AQ station.

caused by the weather in the area, as we see in Figure 3, when it coincides with maximum temperature events and high levels of solar radiation. Weather conditions in the area, the existence of an oil refinery, the petrochemical industry and transportation sources close to the location of the station indicate that there are several drivers of ozone in the area.

In Figure 8(b) we note that the peaks reached between 208 and $240 \mu \mathrm{g} / \mathrm{m}^{3}$, exceeding 15 times the NOM020-SSA1-2014 of Mexico and 21 times the EU limit values; however, discrepancies seen in some months affect the observations, probably caused by miss-calibrations or improper handling of the equipment. The 8H observations in Figure 8(b) show the same tendency to exceed the limit values of Mexico $\left(137 \mu \mathrm{g} / \mathrm{m}^{3}\right)$, EU (120 $\left.\mu \mathrm{g} / \mathrm{m}^{3}\right)$, NAAQS $\left(147 \mu \mathrm{g} / \mathrm{m}^{3}\right)$ and the WHO of $100 \mu \mathrm{g} / \mathrm{m}^{3}$. The $8 \mathrm{HLV}$ regulation from Mexico was exceeded four times and the WHO guideline was exceeded 32 times.

Figure 8(c) and Table 8 corresponding to the Minatitlan station, show the concentration levels limit values (LV) of $\mathrm{SO}_{2}$ and statistics of $\mathrm{H}, 8 \mathrm{HA}, \mathrm{DA}$ and Annual (A) average of the periods. The $\mathrm{H}$ mean values were 15, 34 and $46 \mu \mathrm{g} / \mathrm{m}^{3}$ with a standard deviation of 23,34 and $30 \mu \mathrm{g} / \mathrm{m}^{3}$. 8HA values were 15,34 and $45 \mu \mathrm{g} / \mathrm{m}^{3}$ with a standard deviation of 14,22 and $17 \mu \mathrm{g} / \mathrm{m}^{3}$. Finally, the D mean values were 15,34 and $45 \mu \mathrm{g} / \mathrm{m}^{3}$ with a standard deviation of 9, 17 and $10 \mu \mathrm{g} / \mathrm{m}^{3}$. In Figure 9, the hourly trend of $\mathrm{SO}_{2}$ shows a gradual increase in the average concentration of 30 to $46 \mu \mathrm{g} / \mathrm{m}^{3}$ from 19:00 to 10:00, gradually decreasing after reaching $34 \mu \mathrm{g} / \mathrm{m}^{3}$ at $18: 00$. When reviewing the weekly trend, Monday shows the highest average at $35 \mu \mathrm{g} / \mathrm{m}^{3}$, declining on Tuesday to 32 $\mu \mathrm{g} / \mathrm{m}^{3}$, and increasing again on Wednesday, Thursday, Friday and Saturday, decreasing again on Sunday. This pattern indicates that the source related to traffic and the use of diesel as fuel, is present during the hours and days of greatest urban activity, with cargo transport of the industrial zone that supplies the refinery and petrochemical plants, helping to exceed the thresholds.

Annual analysis shows that months of February, March and April have the maximum average values, around $40 \mu \mathrm{g} / \mathrm{m}^{3}$, and the rest of the months decrease from 20 to $30 \mu \mathrm{g} / \mathrm{m}^{3}$. This pattern corresponds with periods of rain (see Table 2); the months with less precipitation give higher values of $\mathrm{SO}_{2}$ and vice versa.

The limit values $8 \mathrm{HLV}$ of $524 \mu \mathrm{g} / \mathrm{m}^{3}$ and DLV of $288 \mu \mathrm{g} / \mathrm{m}^{3}$ of the Mexican NOM-022-SSA1-2010 were not exceeded. However, it can be seen in Figure 8(c) that the ALV $66 \mu \mathrm{g} / \mathrm{m}^{3}$ of Mexico, the DLV of WHO 20 $\mu \mathrm{g} / \mathrm{m}^{3}$ and the HLV $350 \mu \mathrm{g} / \mathrm{m}^{3}$ of the EU directive were exceeded several times in the period analyzed.

The observations and statistics shown in Figure 8(d) and Table 8 respectively show the values HA, DA and annual $\mathrm{PM}_{10}$ for the period analyzed. The HA values were 38,37 and $38 \mu \mathrm{g} / \mathrm{m}^{3}$ with a standard deviation of 23 , 20 and $28 \mu \mathrm{g} / \mathrm{m}^{3}$; while the DA values were 39,40 and $39 \mu \mathrm{g} / \mathrm{m}^{3}$ with a standard deviation of 19,13 and 19 $\mu \mathrm{g} / \mathrm{m}^{3}$. In Figure $8(\mathrm{e})$ and Table 8 for $\mathrm{PM}_{2.5}$, the HA values were 23,20 and $13 \mu \mathrm{g} / \mathrm{m}^{3}$ with a standard deviation of 11,10 and $13 \mu \mathrm{g} / \mathrm{m}^{3}$; and a DA of 23,19 and $13 \mu \mathrm{g} / \mathrm{m}^{3}$ with a standard deviation of $11,10 \mathrm{and} 8 \mu \mathrm{g} / \mathrm{m}^{3}$.

Figure 9, analyzing the hourly pattern of $\mathrm{PM}_{10}$ and $\mathrm{PM}_{2.5}$, shows that the minimum average value of $34 \mu \mathrm{g} / \mathrm{m}^{3}$ occurs at 05:00, gradually increases and at 08:00 it reaches the value of $45 \mu \mathrm{g} / \mathrm{m}^{3}$, then decreases and remains 
between $40 \mu \mathrm{g} / \mathrm{m}^{3}$ from 09:00 to 17:00, increasing at 20:00 and declining again up to $40 \mu \mathrm{g} / \mathrm{m}^{3}$ at 23:00. $\mathrm{PM}_{2.5}$ values could not be estimated. In the weekly trend, Mondays and Tuesdays have the highest average values of 45 and $23 \mu \mathrm{g} / \mathrm{m}^{3}, \mathrm{PM}_{10}$ and $\mathrm{PM}_{2.5}$ respectively, diminishing gradually towards Friday, afterwards gradually increasing at the weekend to 40 and $21 \mu \mathrm{g} / \mathrm{m}^{3}$ respectively. When the monthly trend of $\mathrm{PM}_{10}$ and $\mathrm{PM}_{2.5}$ is observed, similar patterns are seen: an increase in the months of January to April, decreasing from May to June, increasing again from July to August and decreasing again in September and October, to restart the increasing trend until December. This behavior may be related to the activity of urban and cargo traffic, industrial activities of the MZ and meteorological aspects related to rainfall and temperature in the area.

Comparing observations with the Mexican standard $\mathrm{PM}_{10}$ and $\mathrm{PM}_{2.5}$ NOM-025-SSA1-2014, the WHO guidelines, the standards of the USA-NAAQ and the EU directive, Figure 8(d) shows that the DLV and ALV of 40 and $20 \mu \mathrm{g} / \mathrm{m}^{3}$ respectively were exceeded several times. The DLV and ALV limits for $\mathrm{PM}_{2.5}, 45$ and $12 \mu \mathrm{g} / \mathrm{m}^{3}$, shown in Figure 8(e), also were exceeded; unfortunately several observations in 2015 were missed and a complete analysis couldn't be done.

\subsection{Discussions and Comparisons}

The Xalapa station, located in the capital city of the state, is classified as an urban station with traffic influence. Comparing the $2014 \mathrm{NO}_{2}$ mean of $22 \mu \mathrm{g} / \mathrm{m}^{3}$ with AQ urban values in Latin America [9] from 10 to $70 \mu \mathrm{g} / \mathrm{m}^{3}$, the AQ can be considered good to moderate. The Mexican legislation was not exceeded but the WHO standards were exceeded several times. The Minatitlan station near an industrial area and a main road was classified as urban-industrial with traffic influences; it was observed that in the year 2014 the Minatitlan station did not exceed the mean LV of $17 \mu \mathrm{g} / \mathrm{m}^{3}$ of Mexican legislation, but the WHO guidelines were exceeded again, and therefore considered an AQ from moderate to bad; in comparison with the CAI-2011 report the AQ in Minatitlan station can be considered good to moderate.

The $\mathrm{O}_{3}-8 \mathrm{H}$ annual mean value in 2014 of $44 \mu \mathrm{g} / \mathrm{m}^{3}$ at Xalapa station, compared with the urban values of the CAI-2011 report of 20 to $70 \mu \mathrm{g} / \mathrm{m}^{3}$, indicated an AQ of moderate, and this value compared with Mexican legislation results in an AQ of good to moderate, as observations were not exceeded, but in the Minatitlan station the annual mean of $52 \mu \mathrm{g} / \mathrm{m}^{3}$ compared with CAI-2011 report gave an AQ from moderate to bad, and when compared with Mexican legislation and WHO guidelines, it was observed that the LV was also exceeded.

The Xalapa station observations of $\mathrm{SO}_{2}$ show an annual mean of $11 \mu \mathrm{g} / \mathrm{m}^{3}$. This value was compared with the CAI-2011 from 0 to $25 \mu \mathrm{g} / \mathrm{m}^{3}$, giving a good AQ. According to Mexican legislation the LV was not exceeded. When the mean of $34 \mu \mathrm{g} / \mathrm{m}^{3}$ at Minatitlan station is compared with the CAI-2011, it was observed that it was exceeded and therefore a bad AQ was obtained; the 2014 observations did not exceed Mexican legislation but exceeded the WHO standards, and therefore considered an AQ of moderate to bad for this pollutant.

The $\mathrm{PM}_{10}$ DA mean of $38 \mu \mathrm{g} / \mathrm{m}^{3}$ in 2014 at Xalapa station compared with the CAI-2011 from 20 to $90 \mu \mathrm{g} / \mathrm{m}^{3}$, gave an AQ that can be considered moderate: both Mexican legislation and the WHO guidelines were exceeded in their LV. At Minatitlan station the DA mean of $40 \mu \mathrm{g} / \mathrm{m}^{3}$, compared with the CAI-2011, also gave an AQ of moderate, and it was observed that both Mexican legislation and the WHO guidelines were again exceeded.

The $\mathrm{PM}_{2.5}$ DA mean of $17 \mu \mathrm{g} / \mathrm{m}^{3}$ of 2014 at Xalapa station, compared with CAI-2011 values from 0 to 40 $\mu \mathrm{g} / \mathrm{m}^{3}$, gave an AQ that could be considered as good to moderate; according to Mexican legislation the LV were exceeded several times; similarly, the WHO guidelines were exceeded too. The Minatitlan's station shows an annual mean of $19 \mu \mathrm{g} / \mathrm{m}^{3}$ which, compared with the CAI-2011 values, gave an AQ of good to moderate; both Mexican legislation and the WHO standards were exceeded several times. Finally, it was found that the ratio of $\mathrm{PM}_{2.5} / \mathrm{PM}_{10}$ was 0.5 at Xalapa and Minatitlan AQ stations.

\section{Conclusions}

The data analyzed in this paper show that in MZ with 500,000 inhabitants or more, as Xalapa or Minatitlan, the daily traffic, industrial and cargo transport activities affect the AQ by vehicle emissions of pollutants such as particulate matter $\left(\mathrm{PM}_{10}\right.$ and $\left.\mathrm{PM}_{2.5}\right)$ and gases such as $\mathrm{SO}_{2}, \mathrm{NO}_{2}$ and $\mathrm{O}_{3}$. The diurnal patterns in both $\mathrm{MZ}$ strongly reflected morning and evening traffic. In addition, lower weekend concentrations were observed.

The activities related to the petroleum refining, petrochemical and agrochemical development increase the thresholds of pollutants such as $\mathrm{SO}_{2}, \mathrm{NO}_{2}$ and $\mathrm{O}_{3}$. The urbanization activities of land-use change, burning of areas for agriculture or forest fires might contribute to increase particulate matter in the study areas. 
The results in both areas show higher concentration of pollutants such as $\mathrm{O}_{3}, \mathrm{SO}_{2}$ and $\mathrm{NO}_{2}$ in the metropolitan area of Minatitlan. This effect is a sum of emissions from road traffic plus the oil refining industry emissions. In both areas, the particulate material $\left(\mathrm{PM}_{10}\right.$ and $\left.\mathrm{PM}_{2.5}\right)$ has high thresholds that tend to surpass Mexican regulations, WHO guidelines and international AQ standards.

The results of $\mathrm{NO}_{2}$ and $\mathrm{SO}_{2}$ from MZs in Xalapa and Minatitlan in Veracruz state in Mexico, when compared to concentration indicators in [9] Latin America report or values of the EMEP stations Spain [54] show that background $\mathrm{HA}$ values are normal in both stations. The $\mathrm{HA}$ and $8 \mathrm{HA} \mathrm{O}_{3}$ observations at the Minatitlan station according to Mexican standards sometimes exceeded the $\mathrm{LV}$. The values of $\mathrm{PM}_{10}$ and $\mathrm{PM}_{2.5}$ at both stations were unsatisfactory, as the Mexican standard was exceeded on several occasions. This analysis should be considered in the case of the Minatitlan station because there were equipment failures, leading to lower reliability in this analysis of the data observed in 2015.

In the metropolitan area of Xalapa in reviewing the monthly trends, high levels of $\mathrm{NO}_{2}, \mathrm{SO}_{2}$ and particulates are observed during the months of December to May. From June to September, ozone levels increase. In the metropolitan area of Minatitlan, the trend of higher levels of pollutants occurs between the months of January to September, diminishing from September to December. The rainy season, solar radiation, midsummer, north and south winds contribute to the observed patterns.

MZs in Veracruz state show a tendency to increase their population and therefore the use of transport, services and job creation might affect the AQ. Veracruz state [16] has a great number of MZs and included in this list there are at least three areas with industrial developments such as Orizaba, Coatzacoalcos-Minatitlan and Poza Rica, and two with a high level of urban commercial development, as seen in Xalapa and Veracruz-Boca del Rio; if this trend continues, the urban development might affect values of current AQ, resulting in a negative change in those metropolitan areas.

Finally, SEDEMA should consider these results as good reason to improve the operating conditions of the AQ stations and improve the network that is beginning to settle in the state of Veracruz, and support functional and operational approaches in the AQMP (ProAire Veracruz), which is under development.

\section{Acknowledgements}

Thanks to the National Council of Research and Technology (CONACyT), The Universidad Veracruzana in Mexico and the Barcelona Supercomputing Center-National Center of Supercomputing (BSC-CNS) in Spain for their valued support of this postdoctoral fellowship. Thanks to the SEDEMA in Veracruz, Mexico, for the datasets that support this article and research about the Air Quality in the state. Special thanks also to the group at the Earth Sciences Department for their support and guidance.

\section{References}

[1] WHO_Air Quality Reports (2013).

http://www.euro.who.int/_data/assets/pdf_file/0004/193108/REVIHAAP-Final-technical-report-final-version.pdf?ua= $\underline{1}$

[2] Bedoya, J. and Martínez, E. (2009) Calidad del Aire en el Valle de Aburrá Antioquia -Colombia. DYNA, 76, 7-15. http://www.scielo.org.co/scielo.php?script=sci_arttext\&pid=S0012-73532009000200001\&lng=en\&tlng=es

[3] Gemmer, M. and Xiao, B. (2013) Air Quality Legislation and Standards in the European Union: Background, Status and Public Participation. Advances in Climate Change Research, 4, 50-59. http://dx.doi.org/10.3724/SP.J.1248.2013.050

[4] Guerreiro, C.B.B., Foltescu, V. and de Leeuw, F. (2014) Air Quality Status and Trends in Europe. Atmospheric Environment, 98, 376-384. http://dx.doi.org/10.1016/j.atmosenv.2014.09.017

[5] Vestreng, V., Myhre, G., Reis, S. and Tarrasón, L. (2007) Twenty-Five Years of Continuos Sulphur Dioxide Emission Reduction in Europe. Atmospheric Chemistry and Physics, 7, 3663-3681. http://dx.doi.org/10.5194/acp-7-3663-2007

[6] Derwent, R.G., Simmonds, P.G., Manning A.J. and Spain, T.G. (2007) Trends over a 20-Year Period from 1987 to 2007 in Surface Ozone at the Atmospheric Research Station, Mace Head, Ireland. Atmospheric Environment, 41, 90919098. http://dx.doi.org/10.1016/j.atmosenv.2007.08.008

[7] Hensel, S., Le Tertre, A.,Atkinson, R.W., Querol, X., Pandolfi, M., Zeka, A., Haluza, D., Analitis, A, Katosouyanni, K., Bouland, C., Pascal, M., Medina, S. and Goodman, P.G. (2015) Trends of Nitrogen Oxides in Ambient Air in Nine European Cities between 1999 and 2010. Atmospheric Environment, 117, 234-241. 
http://dx.doi.org/10.1016/j.atmosenv.2015.07.013

[8] Nguyen, H.T and Kim, K. (2006) Changes in $\mathrm{NO}_{2}$ Concentration from Major Cities and Provinces in Korea: A Case Study from 1998 to 2003. TAO, 17, 277-294.

[9] CAI-LAC (Clean Air Institute) (2013) Calidad del aire en America Latina: Una visión panorámica, Washington DC. http://www.cleanairinstitute.org/calidaddelaireamericalatina/cai-report-spanish.pdf

[10] Baldasano, J.M., Valera, E. and Jiménez, P. (2003) Air Quality Data from Large Cities. The Science of the Total Environment, 307,141-165. http://dx.doi.org/10.1016/S0048-9697(02)00537-5

[11] Lanzafame, R., Scandura Francesco, P., Famoso, F., Monforte, P. and Oliveri, C. (2014) Air Quality Data for Catania: Analysis and Investigation Case Study 2010-2011. Energy Procedia, 45, 681-690. http://dx.doi.org/10.1016/j.egypro.2014.01.073

[12] Titos, G., Lyamani, H., Drinovec, L., Olmo, F.J., Močnik, G. and Alados-Arboledas, L. (2015) Evaluation of the Impact of Transportation Changes on Air Quality. Atmospheric Environment, 114, 19-31. http://dx.doi.org/10.1016/j.atmosenv.2015.05.027

[13] Kanabkaew, T., Nookongbut, P. and Soodjai, P. (2013) Preliminary Assessment of Particulate Matter Air Quality Associated with Traffic Emissions in Nakhon Si Thammarat, Thailand. Procedia Engineering, 53, 179-184. http://dx.doi.org/10.1016/j.proeng.2013.02.023

[14] Prakash Sharma, A., Kim, K., Anh, J., Shon, Z., sohn, J., Lee, J., Ma, Ch. and Brown, R.J.C. (2014) Ambient Particulatte Matter (PM10) Concentrations in Major Urban Areas of Korea during 1996-2010. Atmospheric Pollution Research, 5, 161-169. http://www.atmospolres.com/articles/Volume5/issue1/APR-14-020.pdf

[15] Calderón-Garcidueñas, L., Kulesza, R.J., Doty, R.L., D’Angiulli, A. and Torres-Jardón, R. (2015) Megacities Air Pollution Problems: Mexico City Metropolitan Area Critical Issues on the Central Nervous System Pediatric Impact. Environmental Research, 137,157-169. http://dx.doi.org/10.1016/j.envres.2014.12.012

[16] CONAPO-Mexico (National Council of Population) (2010). http://www.conapo.gob.mx/es/CONAPO/Zonas_metropolitanas_2010

[17] Veracruz-Goverment (2012) Veracruz y la energía La importancia de su participación en el desarrollo energético del país y en la reforma propuesta para el sector. http://www.veracruz.gob.mx/wp-content/uploads/2012/01/tf07-pvd08-10-ver-energia.pdf

[18] INEGI (National Institute of Statistics, Geography and Informatic) (2011). http://cuentame.inegi.org.mx/monografias/informacion/ver/economia/infraestructura.aspx?tema=me

[19] INEGI-Mexico (National Institute of Statistics, Geography and Informatic) (2010) Censo de Población y vivienda 2010. http://www.censo2010.org.mx/

[20] INEGI (National Institute of Statistics, Geography and Informatic) (2009). http://www3.inegi.org.mx/sistemas/mexicocifras/datos-geograficos/30/30087.pdf

[21] Vázquez, P. (2008) Análisis de la Tendencia de la Precipitación y la Niebla de la Zona Montañosa Central de Veracruz. Grade Thesis. Facultad de Instrumentación Electrónica y Ciencias Atmosféricas, Universidad Veracruzana, Xalapa.

[22] INEGI (National Institute of Statistics, Geography and Informatic) (2009). http://www3.inegi.org.mx/sistemas/mexicocifras/datos-geograficos/30/30108.pdf

[23] SMN-CNA-Mexico (National Meteorological Service, National Comission of Water) (2015). http://smn.cna.gob.mx/index.php?option=com_content\&view=article\&id=164\&tmpl=component

[24] Biodiversity of Mexico (2012). http://www.biodiversidad.gob.mx/region/EEB/pdf/Veracruz/Volumen_I/Seccion_I.pdf

[25] INEGI (National Institute of Statistics, Geography and Informatic) (2011). http://www.cuentame.inegi.org.mx/monografias/informacion/ver/territorio/clima.aspx?tema=me\&e=30

[26] SMN-CNA-Mexico (National Meteorological Service, National Comission of Water) (2015). http://smn.cna.gob.mx/climatologia/canicula/canicula.pdf

[27] Zavala-Hidalgo, J., Romero-Centeno, R., Mateos-Jasso, A., Morey, Steven L. and Martínez-López, B. (2014) The Response of the Gulf of Mexico to Wind and Heat Flux Forcing: What Has Been Learned in Recent Years? Atmósfera, 27, 317-334. http://www.scielo.org.mx/scielo.php?script=sci_arttext\&pid=S0187-62362014000300008\&lng=es\&tlng=en

[28] SMN-CNA-Mexico (National Meteorological Service, National Comission of Water) (2015). http://smn.cna.gob.mx/ciclones/tempo2005/rt2005a.pdf

[29] SEMAR-Mexico (MexicanNavy) (2013). http://meteorologia.semar.gob.mx/resumen_ciclones_tropicales_2013.pdf

[30] SEMAR-Mexico (Mexican Navy) (2014).

http://meteorologia.semar.gob.mx/ciclones/resumen_ciclones_tropicales_2014.pdf 
[31] Pérez R. (2005) CartographyDirect Solar Radiationfrom USAID. http://prod-http-80-800498448.us-east-1.elb.amazonaws.com/w/images/0/0a/SWERA-276.pdf

[32] Veracruz Government (2014) Programa Estatal de Calidad del Aire Portal del Gobierno del estado de Veracruz SEDEMA. http://www.veracruz.gob.mx/blog/2014/06/10/169637/

[33] Lodge, J.P. (1988) ebook: Methods of Air Sampling and Analysis. 3rd Edition. CRC Press, Boca Raton.

[34] ADEC-US (Alaska Department of Environmental Conservation) (2012) Standar Operating Procedures for $\mathrm{SO}_{2} \mathrm{Moni}^{-}$ toring by UV-Fluorescence. https://dec.alaska.gov/air/am/SO2_SOP_13feb12.pdf

[35] Williams, K., Fairchild, C. and Jaklevic, J. (1993) Dynamic Mass Measurement Techniques in Aerosol Measurement. In: Willeke, K. and Baron, P., Eds., Principles, Techniques and Applications, Van Nostrand Reinhold, New York, 296312.

[36] INECC-Mexico (National Institute of Ecology and Climate Change) (2013) Manual 3.-Redes Estaciones y Equipos de Medicion de la Calidad del Aire, México. http://www2.inecc.gob.mx/publicaciones/download/623.pdf

[37] Gobeli, D., Schloesser, H. and Pottberg T. (2008) Met One Instruments BAM-1020 Beta Attenuation Mass Monitor US-EPA PM P.. $_{2.5}$ Federal Equivalent Method Field Test Results Paper \#2008-A-485-AWMA. http://www.metone.com/docs/bam1020_whitepaper_2008a485awma.pdf

[38] INECC-Mexico (National Institute of Ecology and Climate Change) (2013) Manual 5.-Protocolo del manejo de datos de la calidad del aire, México. http://www2.inecc.gob.mx/publicaciones/download/625.pdf

[39] CALIOPE (Air Quality Operational) (2014) Observations Database Filter. http://www.bsc.es/projects/earthscience/visor/bases_datos/image_viewer/docs/20140212_Filtrado_de_observaciones_ BBDD_esp.pdf

[40] SEMARNAT-Mexico (Secretaria del Medio Ambiente y Recursos Naturales) (2012) NOM-156-SEMARNAT-2012 Establecimiento y operación de sistemas de monitoreo de la calidad del aire.

[41] Carslaw, D.C. and Ropkins, K. (2012) openair-An R Package for Air Quality Data Analysis. Environmental Modelling And Software, 27-28, 52-61. http://dx.doi.org/10.1016/j.envsoft.2011.09.008

[42] Carslaw, D.C. (2013) The Openair Manual-Open Source Tools for Analysing Air Pollution Data. Manual for Versión 0.8-0. King’s College London, London. http://www.openair-project.org/Downloads/OpenAirManual.aspx

[43] R Development Core Team (2011) R: A Language and Environment for Statistical Computing. R Foundation for Statistical Computing, Vienna.

[44] CE-Directive (2008) Directiva 2008/50/CE del Parlamento Europeo y del Consejo relativa a la calidad del aire ambiente y a una atmósfera más limpia en Europa.

http://eur-lex.europa.eu/LexUriServ/LexUriServ.do?uri=OJ:L:2008:152:0001:0044:Es:PDF

[45] WHO-Air Quality Guidelines (2005) 173-198. http://www.euro.who.int/ data/assets/pdf file/0005/74732/E71922.pdf

[46] NAAQ-USA (2012a) National Air Quality Standards-USA. http://www3.epa.gov/pm

[47] SEMARNAT-Mexico (Secretaria del Medio Ambiente y Recursos Naturales) (2015) LGEEPA (Ley General del Equilibrio Ecológico y Protección al Ambiente).

http://biblioteca.semarnat.gob.mx/janium/Documentos/Ciga/agenda/DOFsr/148.pdf

[48] DOF-Mexico (Diario Oficial de la Federación) (2012) NOM-156-SEMARNAT-2012 Establecimiento y operación de sistemas de monitoreo de la calidad del aire. http://biblioteca.semarnat.gob.mx/janium/Documentos/Ciga/agenda/DOFsr/DO2892.pdf

[49] INECC-Mexico (NationalInstitute of Ecology and ClimateChange) (2011) Primer catalogo de estaciones de monitoreo en Mexico. http://www2.inecc.gob.mx/publicaciones/libros/681/cap1.pdf\#page=2\&zoom=auto,-127,32

[50] DF-Mexico (Web of Air Qualityfrom D.F.-Mexico) (1994) NOM-023-SSA1-1993 Salud Ambiental. Criterio para evaluar la calidad del aire ambiente con respecto al bióxido de nitrógeno $\left(\mathrm{NO}_{2}\right)$. Valor normado para la concentración de bióxido de nitrógeno (NO2) en el aire ambiente como medida de protección a la salud de la población. http://www.aire.df.gob.mx/descargas/monitoreo/normatividad/NOM-023-SSA1-1993.pdf

[51] DOF-Mexico (Diario Oficial de la Federación) (2014) NOM-020-SSA1-2014 Salud Ambiental Valor límite permisible para la concentración de ozono (O3) en el aire ambiente y criterios para su evaluación. http://www.dof.gob.mx/nota_detalle.php?codigo=5356801\&fecha=19/08/2014

[52] DOF-Mexico (Diario Oficial de la Federación) (2010) NOM-022-SSA1-2010 Salud Ambiental.Criterio para evaluar la calidad del aire ambiente, con respecto al dióxido de azufre (SO2). Valor normado para la concentración de dióxido de azufre $\left(\mathrm{SO}_{2}\right)$ en el aire ambiente, como medida de protección a la salud de la población. http://www.dof.gob.mx/normasOficiales/4149/salud1/salud1.htm 
[53] DOF-Mexico (Diario Oficial de la Federación) (2014) NOM-025-SSA1-2014 Salud Ambiental Valores límite permisibles para la concentración de partículas suspendidas PM10 y PM2.5 en el aire ambiente y criterios para su evaluación. http://www.dof.gob.mx/nota_detalle.php?codigo=5357042\&fecha=20/08/2014

[54] EMEP-Database (2000). http://www.ceip.at/ms/ceip home1/ceip home/webdab emepdatabase/ 